\title{
The influence of diagenetic alterations on porosity in the Triassic Narrabeen Group, Southern Sydney Basin, Australia
}

\author{
Fahad AL GAHTANI ${ }^{1, *}$ \\ 1 Ministry of Petroleum and Mineral Resources, PO Box 247, Riyadh 11189, Saudi Arabia
}

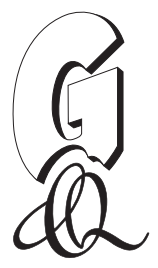

Al Gahtani F. (2013) The influence of diagenetic alterations on porosity in the Triassic Narrabeen Group, Southern Sydney Basin, Australia. Geological Quarterly, 57 (4): 613-628, doi: 10.7306/gq1109

\begin{abstract}
Petrography of the Triassic Narrabeen Group (Southern Sydney Basin of Australia) was described by thin section, scanning electron microscope and X-ray diffraction techniques. Sandstone composition includes mostly lithic grains with minor quartz, feldspar, mica and heavy minerals; litharenites and sublitharenites are common and quartzarenites are rare. Quartz includes monocrystalline and polycrystalline grains while the feldspar includes both K-feldspar and plagioclase. Volcanic, sedimentary and chert rock fragments are present. In thin section porosity is visible in all units, particularly the coarse-grained deposits. Secondary porosity is greater than the primary porosity. The diagenetic alterations include compaction, quartz overgrowths, authigenic clay minerals, carbonate cement and authigenic feldspar. Compaction occurred in all units during diagenesis. Both early and late diagenetic carbonate cement is important in the Narrabeen Group. Pore-filling carbonate cement reduced porosity whereas dissolution of carbonate resulted in secondary porosity. Authigenic clay minerals are widespread in all units filling pores and occurring as grain-coatings on detrital and authigenic grains. Where they coat quartz grains they preserve porosity by preventing growth of quartz overgrowths. Dissolution of unstable feldspar and lithic grains provided secondary porosity. In the Narrabeen Group, shale and siltstone are abundant in the Wombarra Claystone, Stanwell Park Claystone, Bald Hill Claystone and Newport Formation, forming lithological seals and confining layers. Minor sandstone beds occur in the Wombarra Claystone and contain more porosity. Medium- and coarse-grained sandstone is common in the Coalcliff Sandstone, Scarborough Sandstone and Bulgo Sandstone and shows low to moderate porosity. Thus, these sandstone units probably contain gas or water.
\end{abstract}

Key words: petrography, diagenesis, primary porosity, secondary porosity, quartz overgrowth, carbonate cement.

\section{INTRODUCTION}

In the Sydney Basin (Australia), the Narrabeen Group is the lowermost of three Triassic rock units and is located between the Upper Permian Illawarra Coal Measures and the Hawkesbury Sandstone (Ward, 1971a). Fine-grained sediment in the Narrabeen Group was previously studied by several authors (e.g., Baker, 1956; Loughnan et al., 1964, 1974; Goldbery and Holland, 1973; Retallack, 1977). Ward (1972) noted quartzose, quartz-lithic and volcanic sandstones as the three sediment suites in the Narrabeen Group. Provenance markers of foreland basin-fill sediments were determined by Cowan (1993). The composition and texture of the Narrabeen Group were described by McElroy (1954). Descriptions of the petrology in the Narrabeen Group have been conducted by numerous authors (e.g., Loughnan, 1963; Ward, 1971a, b; Bai, 1991; Dehghani, 1994; Bai and Keene, 1996). These studies showed that quartz, rock fragments, feldspar and clay minerals are present in the Narrabeen Group. Also, siderite, heavy minerals,

\section{*E-mail: fmhag159@uowmail.edu.au}

Received: April 16, 2013; accepted: June 27, 2013; first published online: June 29, 2013 mica and iron oxide are present in the Narrabeen Group (Dehghani, 1994; Bai and Keene, 1996).

Reservoirs quality were studied by some authors such as Hamilton and Galloway (1989) and Mullard (1995). Hamilton and Galloway (1989) indicated that the Coalcliff Sandstone is poor reservoir whereas Mullard (1995) showed that the Stanwell Park Claystone, Bald Hill Claystone and Wombarra Claystone would be good seals in the Narrabeen Group. Also, Mullard (1995) indicated that Bulgo Sandstone rather than in the Coalcliff Sandstone and Scarborough Sandstone could be hydrocarbon reservoirs in the Narrabeen Group. Mullard (1995) showed that hydrocarbons were generated from the Coalcliff Sandstone, thus gas was generated in the Narrabeen Group.

The purpose of this study is to investigate the diagenetic history of the reservoir sandstones and the relationship between the preservation of primary porosity and the generation of secondary porosity in the Narrabeen Group of Southern Sydney Basin, Australia.

\section{GEOLOGICAL SETTING}

The study area is located in the southern Sydney Basin in the Illawarra district of New South Wales, Australia (Fig. 1). In the southern Sydney Basin, the Narrabeen Group is the lowermost of three Triassic rock units and is located between the Upper 


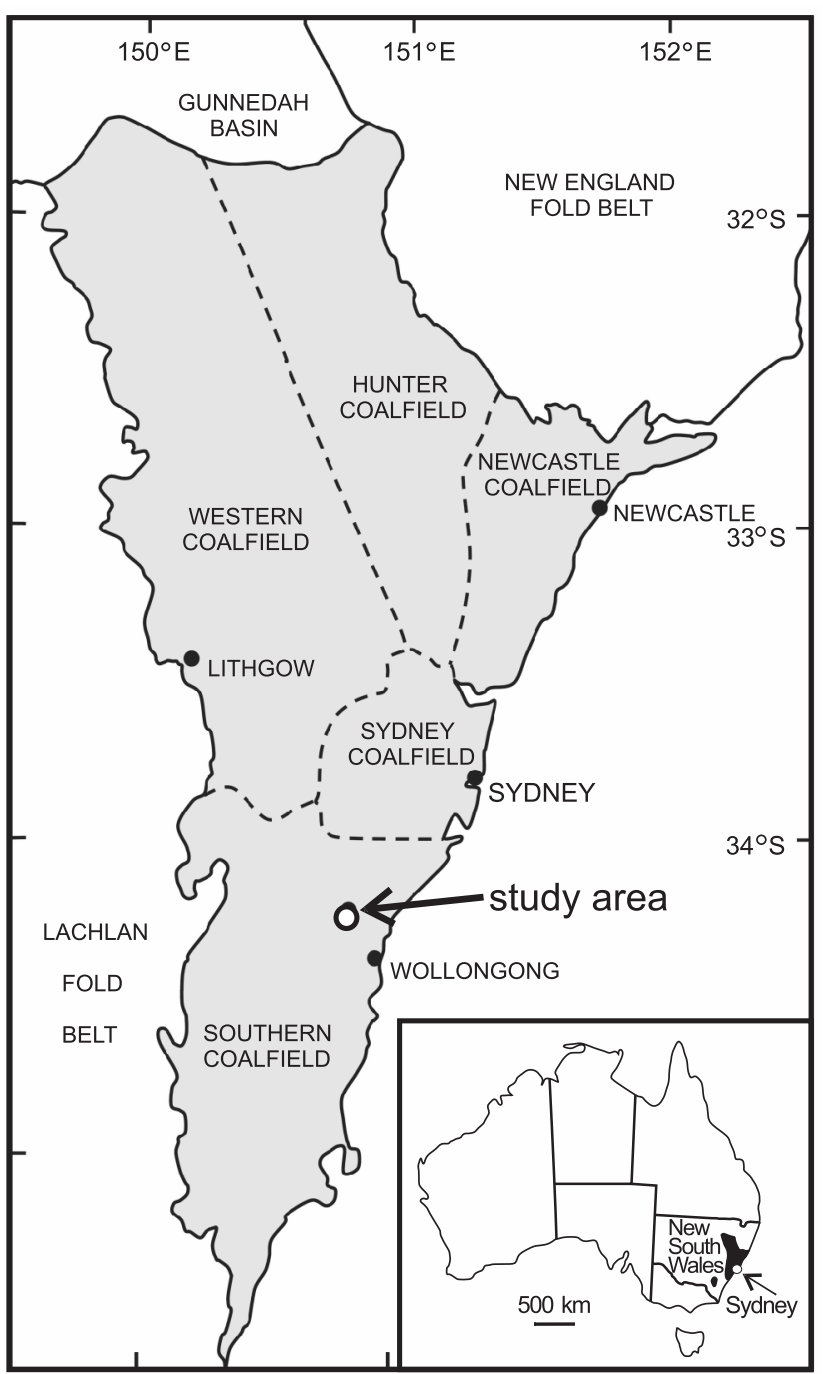

Fig. 1. Location of the Sydney Basin and the Coalfields within it (from Grenvenits et al., 2003)

Permian Illawarra Coal Measures and the Hawkesbury Sandstone (Table 1; Ward, 1971a). Hanlon et al. (1953) conducted a study of the subdivisions of the Narrabeen Group and its correlations between the South Coast and Narrabeen Wyong Districts. They subdivided the Narrabeen Group in the Sydney Basin into the Clifton Subgroup and the Gosford Subgroup (Table 1).

The Clifton Subgroup includes the Coal Cliff Sandstone, Wombarra Claystone, Scarborough Sandstone, Stanwell Park Claystone, Bulgo Sandstone and Bald Hill Claystone (Table 1; Bowman, 1974). Dickson $(1967,1969)$ suggested that the Coal Cliff Sandstone should be introduced as a member of the Wombarra Claystone. The Otford Sandstone Member is a conglomeratic interbed in the Wombarra Claystone (Dehghani and Jones, 1994a). The Scarborough Sandstone is $24 \mathrm{~m}$ thick. The Stanwell Park Claystone has a thickness that varies between 0-37 m, and includes claystone and sandstone intervals. It is overlain by the Bulgo Sandstone, which has a thickness that ranges from 90 to $130 \mathrm{~m}$ (Bowman, 1974). The Bald Hill Claystone overlying the Bulgo Sandstone varies in thickness between 1 and $20 \mathrm{~m}$ (Bowman, 1974).

The Gosford Subgroup consists of the Garie Formation and Newport Formation (Bowman, 1974). Loughnan (1969) recognized the Garie Member at the top of the Bald Hill Claystone and it was later given formation status by Bunny and Herbert (1971).
The Garie Formation includes cream claystone to grey claystone, tuff with accretionary lapilli (Heritage, 2005). The Garie Formation is the lower unit of the Gosford Subgroup and includes cream claystone to grey claystone, tuff with accretionary lapilli (Heritage, 2005). The interbedded dark grey, mudstone, siltstone and fine sandstone of the Newport Formation overlie the Garie Formation and are the upper unit of the Gosford Subgroup (Moffitt, 2000; Heritage, 2005). The Garie Formation and the Newport Formation have thicknesses that range from 0 to $3 \mathrm{~m}$ and from 0 to $18 \mathrm{~m}$, respectively (Bowman, 1974).

\section{METHODS}

The petrography of the Narrabeen Group was based on 153 samples. These samples were selected from outcrop and from nine wells: EAW 30, EAW 42, EAW 156, EDEN 124, EDEN 125 , EDEN 126 and EDEN 127 (Table 2). These samples include 97 sandstone, 18 siltstone, 34 shale and 3 igneous rocks samples. Thin section, X-ray diffraction (XRD) and scanning electron microscope techniques were used to analyse these samples.

Petrographic microscope studies were completed for 76 samples of siltstone, fine-grained sandstone, medium-grained sandstone and coarse-grained sandstone. Before preparation of thin sections, the 76 samples were vacuum impregnated with blue dyed resin for the purposes of description and studying the porosity under the microscope. The determination of modal composition and porosity for the 76 samples were conducted through thin section examination by point counting 400 points per slide.

X-ray diffraction analysis was used to study 122 samples of fine to medium-grained sandstone, fine-grained sandstone, siltstone, shale, tuff, coal and carbonate cement. These samples were prepared for XRD analysis using a Philips (PW3710) diffractometer ( $\mathrm{Cu} \mathrm{K} \alpha$ radiation, $35 \mathrm{kV}, 28.5 \mathrm{~mA}$ ) to determine the percentage of each mineral in fine-grained samples, and clay minerals in the sandstone samples (oriented samples of $<2 \mu \mathrm{m}$ clay fractions). A JEOL JSM-T330 scanning electron microscope (SEM) was used to examine about 28 samples to determine morphology, textural relationships, mineral composition, porosity and diagenetic aspects of the sandstone samples. The description of porosity by SEM depended on the study of pore types. These samples were selected from Bald Hill Claystone, Bulgo Sandstone, Garie Formation, Newport Formation, Stanwell Park Claystone, Scarborough Sandstone, Wombarra Claystone and Coalcliff Sandstone.

\section{RESULTS}

\section{PETROGRAPHY}

The Narrabeen Group is rich in rock fragments and is classified as litharenite to sublitharenite, and rarely quartzarenite $\left(Q_{50.3 \%}, F_{1.4 \%}, R_{48.3 \%}\right.$; Fig. 2A). The Dickinson diagram (1985) shows that samples from the Narrabeen Group plot in the lithic continental, transitional recycled to quartzose recycled and rarely craton interior provenance fields $\left(\mathrm{Qm}_{45.5 \%}, \mathrm{~F}_{1.5 \%}\right.$, $\mathrm{Lt}_{52.9 \%}$; Fig. 2B).

In the Narrabeen Group, the lowest percentage of detrital quartz (5.7\%; Appendix $\left.1^{*}\right)$ was observed in the Coalcliff Sandstone (Fig. 3A). The highest percentage of detrital quartz (85.5\%; Appendix 1) is present in the Newport Formation. Monocrystalline quartz grains exceed polycrystalline quartz grains in most samples. 
Stratigraphy of Southern Coalfield

(after Bunny, 1972; Bowman, 1974, 1980; Carr, 1983; Bamberry, 1992)

\begin{tabular}{|c|c|c|c|c|c|c|}
\hline \multicolumn{3}{|c|}{ Age } & Group & Subgroup & Formation & Member \\
\hline \multirow{11}{*}{ 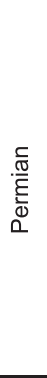 } & \multirow{11}{*}{ 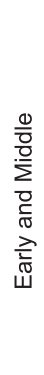 } & & \multirow{2}{*}{$\begin{array}{c}\text { Wianamatta } \\
\text { Group }\end{array}$} & \multirow{2}{*}{$\begin{array}{l}\text { Liverpool } \\
\text { Subgroup }\end{array}$} & Ashfield Shale & \\
\hline & & & & & Mittagong Formation & \\
\hline & & & & & Hawkesbury Sandstone & \\
\hline & & & \multirow{8}{*}{$\begin{array}{l}\text { Narrabeen } \\
\text { Group }\end{array}$} & \multirow{2}{*}{$\begin{array}{l}\text { Gosford } \\
\text { Subgroup }\end{array}$} & Newport Formation & \\
\hline & & & & & Garie Formation & \\
\hline & & & & \multirow{6}{*}{$\begin{array}{l}\text { Clifton } \\
\text { Subgroup }\end{array}$} & Bald Hill Claystone & \\
\hline & & & & & Bulgo Sandstone & \\
\hline & & & & & Stanwell Park Claystone & \\
\hline & & & & & Scarborough Sandstone & \\
\hline & & & & & Wombarra Claystone & $\begin{array}{c}\text { Otford Sandstone } \\
\text { Member }\end{array}$ \\
\hline & & & & & Coal Cliff Sandstone & \\
\hline \multirow{25}{*}{ 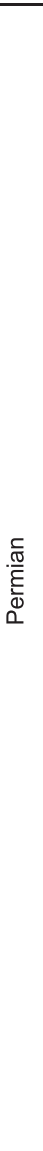 } & & \multirow{25}{*}{ 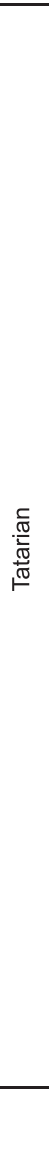 } & \multirow{22}{*}{$\begin{array}{l}\text { Illawarra } \\
\text { Coal } \\
\text { Measures }\end{array}$} & \multirow{16}{*}{$\begin{array}{l}\text { Sydney } \\
\text { Subgroup }\end{array}$} & Bulli Coal & \\
\hline & & & & & Loddon Sandstone & \\
\hline & & & & & \multirow{7}{*}{ Eckersley Formation } & $\begin{array}{l}\text { Balgownie Coal } \\
\text { Member }\end{array}$ \\
\hline & & & & & & $\begin{array}{l}\text { Lawrence Sandstone } \\
\text { Member }\end{array}$ \\
\hline & & & & & & Burragorang Claystone \\
\hline & & & & & & $\begin{array}{c}\text { Cape Horn Coal } \\
\text { Member }\end{array}$ \\
\hline & & & & & & Hargrave Coal Member \\
\hline & & & & & & Woronora Coal Member \\
\hline & & & & & & $\begin{array}{l}\text { Novice Sandstone } \\
\text { Member }\end{array}$ \\
\hline & & & & & Wongawilli Coal & \\
\hline & & & & & Kembla Sandstone & \\
\hline & & & & & Allans Creek Formation & $\begin{array}{c}\text { American Creek Coal } \\
\text { Member }\end{array}$ \\
\hline & & & & & Darkes Forest Sandstone & \\
\hline & & & & & Bargo Claystone & $\begin{array}{c}\text { Austinmer Sandstone } \\
\text { Member }\end{array}$ \\
\hline & & & & & Tongarra Coal & \\
\hline & & & & & Wilton Formation & Woonona Coal Member \\
\hline & & & & & Erins Vale Formation & Kulnura Marine Tongue \\
\hline & & & & & & Figtree Coal Member \\
\hline & & & & Cumberland & & $\begin{array}{c}\text { Unanderra Coal } \\
\text { Member }\end{array}$ \\
\hline & & & & Subgroup & Pheasant Nest Formation & $\begin{array}{l}\text { Tappitallee Mountain } \\
\text { Tuff Member }\end{array}$ \\
\hline & & & & & & Berkeley Latite Member \\
\hline & & & & & & $\begin{array}{c}\text { Minnamurra Latite } \\
\text { Member }\end{array}$ \\
\hline & & & & & Broughton Formation & \\
\hline & \multirow{2}{*}{ 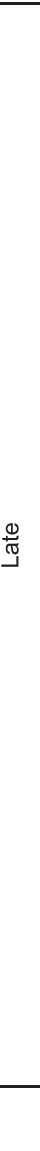 } & & Shoalhaven & & Berry Formation & \\
\hline & & & & & Nowra Sandstone & \\
\hline
\end{tabular}

Feldspar contents are present with percentages that vary between 0 and $2.9 \%$ (Appendix 1) at an average of $0.9 \%$ in sandstone and $0.4 \%$ in siltstone. Rock fragments and chert are the dominant components in the Narrabeen Group. Lithic grains comprise both volcanic and sedimentary rock fragments. Lithic grains vary between 0.5 and $84.4 \%$ (Appendix 1). In this study, chert is present as a major component ranging from 1 to $82 \%$ in the Narrabeen Group and it is observed in all studied samples (Appendix 1).

Up to $10 \%$ muscovite is recorded in the Narrabeen Group (Appendix 1). Heavy minerals are found in trace amounts in the succession, making up between 0.3 and $3.3 \%$ (Appendix 1).

\section{DIAGENESIS AND DIAGENETIC MINERALS}

Quartz overgrowths, authigenic clay minerals, carbonate cement, authigenic feldspar, authigenic pyrite and iron oxide cement are the main authigenic minerals present in the Narra- been Group. Bai and Keene (1996) indicated that the Narrabeen Group includes common authigenic carbonate minerals, clay minerals and quartz. Also, silica dissolution, dissolution of unstable grains such as feldspar and volcanic rock fragments and dissolution carbonate cement were also observed in the Narrabeen Group by Bai and Keene (1996).

Quartz cement. Quartz overgrowths range from 0 to $5.5 \%$ and are found in most samples (Appendix 1). They are more common in quartz-rich sandstone, particularly the Bulgo Sandstone $(3.4 \%)$, than in lithic-rich sandstone. Carbonate is the most common cement and the occurrence of infiltrated clays as coatings on quartz grains means that quartz overgrowths are rare (Salem et al., 2000). Thus, the development of quartz overgrowths is inhibited by grain-coating clays in the Narrabeen Group.

Three types of quartz cement are present in the Narrabeen Group - micro-quartz, mega-quartz and quartz overgrowths (Bai, 1991). Quartz overgrowths form the most common type of quartz cement in the Narrabeen Group. They occur as euhedral 
The general information of studied wells

\begin{tabular}{|l|c|c|c|c|c|}
\hline \multicolumn{1}{|c|}{ Wells } & Site ID & Hole Name & Drilled & Easting & Northing \\
\hline EAW 30 & S1975 & EC Appin West DDH 30 & $25 / 02 / 2009-07 / 04 / 2009$ & 283293.14 & 6219366.32 \\
\hline EAW 42 & S2037 & EC Appin West DDH 42 & $28 / 10 / 2009-25 / 1 / 2010$ & 286735.00 & 6216059.43 \\
\hline EAW 156 & S1996 & EC Appin DDH 156 & $23 / 03 / 2009-06 / 04 / 2009$ & 298772.26 & 6207843.32 \\
\hline EDEN 124 & S2000 & DC Dendrobium DDH 124 & $01 / 04 / 2009-06 / 05 / 2009$ & 290161.39 & 6191011.18 \\
\hline EDEN 125 & S2001 & DC Dendrobium DDH 125 & $23 / 04 / 2009-07 / 05 / 2009$ & 288462.57 & 6192020.03 \\
\hline EDEN 126 & S2002 & DC Dendrobium DDH 126 & $22 / 04 / 2009-07 / 05 / 2009$ & 288633.38 & 6194222.09 \\
\hline EDEN 127 & S2003 & DC Dendrobium DDH 127 & $05 / 05 / 2009-27 / 05 / 2009$ & 290571.12 & 6192478.04 \\
\hline
\end{tabular}

A

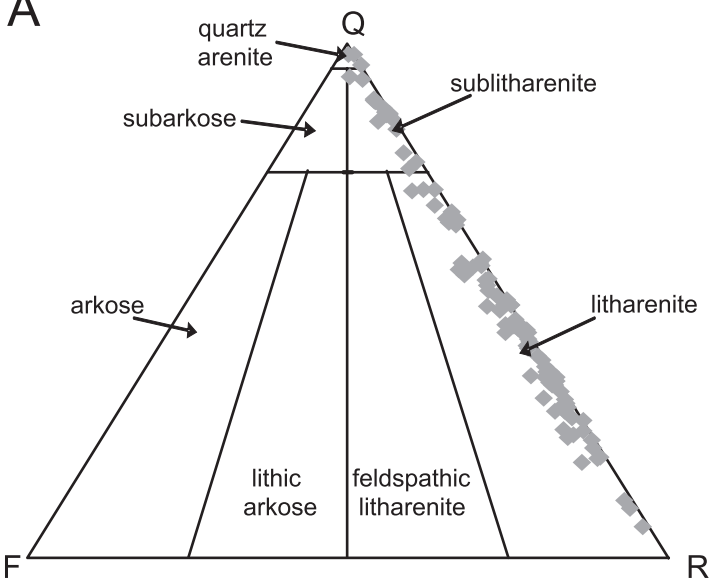

B

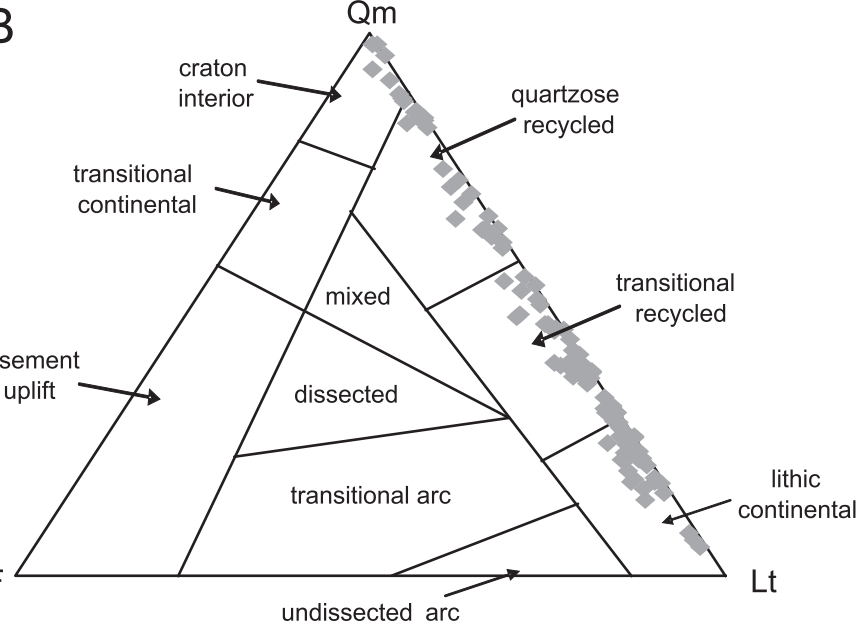

Narrabeen Group

Fig. 2A - classification of the Narrabeen Group (after Folk, 1968), Q - quartz, F - feldspar, R - rock fragment; B - provenance of the Narrabeen Group (after Dickinson, 1985), Qm - monocrystalline quartz, F - feldspar, Lt - rock fragment + chert

crystal faces and partially fill pores between grains (Fig. 3A). Different sizes of quartz overgrowth are observed. Different types of boundaries occur between quartz cement and detrital quartz grains including fluid inclusions, clay coatings and iron oxides. Double quartz overgrowths were observed in rare samples (Fig. 3B).

Authigenic clay minerals. Authigenic clay minerals include kaolinite, illite, mixed-layer illite/smectite and chlorite. They are common and form the second most abundant cement in the Narrabeen Group.

Kaolinite. Kaolinite is distributed throughout the whole of the Narrabeen Group and is the most common authigenic clay. Quartz-rich sandstone contains a greater amount of authigenic kaolinite than lithic-rich sandstone because it contained more available pore spaces. Kaolinite exists as booklets and vermicular aggregates whether separated or in groups, and has rounded to sub-rounded boundaries (Fig. 4B). It fills pore spaces and occurs as coatings on the margins of pores (Fig. 4B). In some samples, it is coated by illite and mixed-layer illite/smectite. Bai (1988) showed that kaolinite is the most widespread diagenetic clay mineral in the Narrabeen Group. The conversion of kaolinite into dickite was observed using SEM where blocky crystals of dickite are thicker than booklets and vermicular aggregates of kaolinite.

Mixed-layer illite/smectite. SEM studies indicated that mixed-layer illite/smectite is common in the Narrabeen Group. In most samples, it coats detrital and authigenic grains and exists as a pore-filling cement (Fig. 4C).
Illite. Illite occurs as fibrous crystals and sheets (Fig. 4D). It is observed as grain coatings on kaolinite and quartz overgrowths (Fig. 4E). Grain-coating illite is characterized as ultra-thin layers and thin mat-like crystals (Fig. 4E). Also, in most samples many intergranular pore spaces are filled with authigenic illite (e.g., McKinley et al., 2011). It is typically oriented perpendicular to grain surfaces and has a high birefringence.

Chlorite. Chlorite is present as authigenic rims around detrital grains (Fig. 4F). It is visible as a pore-filling cement and as grain-coatings in some samples (e.g., Fig. 4F; Bai and Keene, 1996). Pore-filling chlorite is thicker than grain-coating chlorite. Pore-filling chlorite cement has a thickness ranging between 4 and $6 \mu \mathrm{m}$, whereas grain-coating chlorite has a thickness range of 1 to $2 \mu \mathrm{m}$. Grain-coating chlorite is not associated with pore-filling chlorite in the same sample. Moreover, chlorite is associated with mixed-layer illite/smectite and illite in the succession (Fig. $4 \mathrm{~F}$ ). Chlorite is most common in volcanic-rich sandstone.

Carbonate cement. Most samples are cemented by carbonate which is the dominant cement in the Narrabeen Group. Carbonate cement is recorded in all samples varying between 1.5 and $59 \%$ (Appendix 1). Siderite and ankerite are the most common carbonate cements in both the sandstone and siltstone with combined average contents of 6 and $15 \%$, respectively. Less common calcite and dolomite are also present (Bai and Keene, 1996). Two or three types of carbonate cementation are observed in most samples.

Siderite. Siderite is observed in some samples in the Coalcliff Sandstone (0-24.1\%; Appendix 1). Siderite occurs as small 

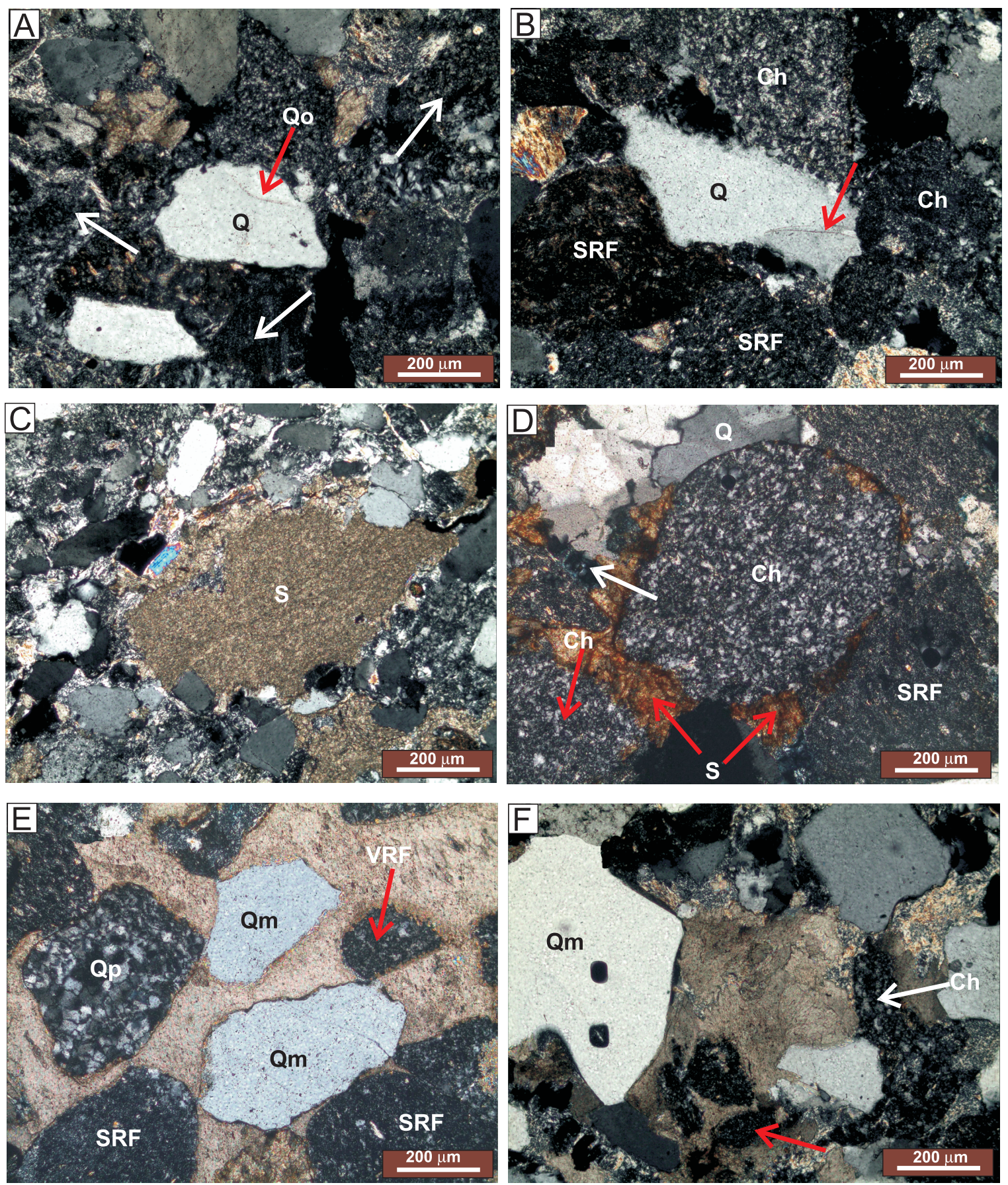

Fig. 3A - quartz overgrowth (Qo) on detrital quartz (Q) fills pore space; also, chert grains (white arrows) are present; B - double quartz overgrowth (red arrow), chert (Ch) and sedimentary rock fragment (SRF) grains are occurred; C - poikilotopic crystals of siderite (S) cement fill a large pore and coats some detrital grains; D - chert (Ch) and sedimentary rock fragment (SRF) are partly coated by early siderite (S) cement; porosity (white arrow) is observed; E - coarse crystalline of ankerite cement is observed as pore-fillings and as grain-coatings on the margins of quartz (Qm, Qp) and rock fragments (VRF, SRF); F - volcanic rock fragment is replaced by ankerite cement (red arrow) which also partly coats the margins of monocrystalline quartz $(\mathrm{Qm})$ and chert $(\mathrm{Ch})$ grains

rhombohedral crystals and as coarse crystalline cement (Fig. $3 C)$. Coarse crystalline siderite is the most widespread carbonate cement in the studied samples, and it includes blocky and poikilotopic crystals (Fig. 3C). Large and small pore spaces are filled with siderite cement that is also present as grain-coatings on detrital and authigenic grains in most samples (Fig. 3C). Many detrital grains are enclosed by siderite cement (Fig. 3D) and some detrital grains, such as feldspar and rock fragment, are replaced by siderite cement. Fluid inclusions are uncom- mon in siderite cement. Siderite is now generally stained with iron oxide because of modern weathering. Alteration of the siderite, ilmenite or iron hydroxides may be the source of the iron oxide coating the siderite (Karim et al., 2010).

Ankerite. It is common in siltstone samples (15\%). Few samples did not include ankerite cement. Three forms of ankerite were observed using SEM including micritic, microcrystalline and coarsely crystalline (Fig. 3E). It fills large and small pores spaces between grains (Fig. 3E) where it occurs as subhedral 

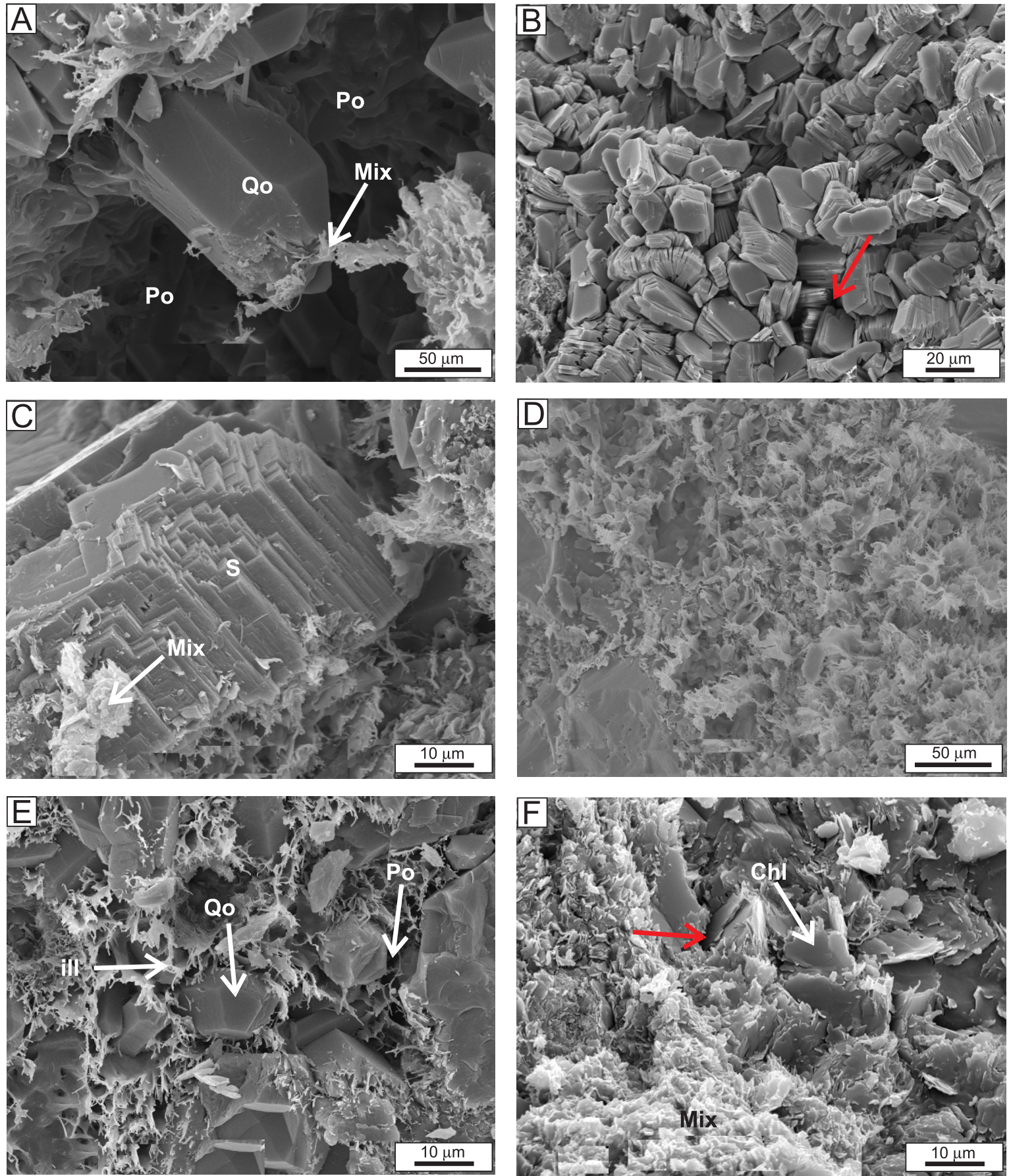

Fig. 4A - quartz overgrowth (Qo) is partly coated by late mixed layer illite/chlorite (Mix), thus large porosity (Po) is observed; B - pore-filling authigenic kaolinite with primary pore (red arrow); C - siderite cement (S) fills a pore and is coated by late diagenetic mixed layer illite/smectite (Mix); D - fibrous authigenic illite occurs as pore-filling; E late stage of ultra-thin layers and thin mat-like crystals of illite (ill) occurs as a grain-coating on quartz overgrowths (Qo); porosity (Po) is present; F - authigenic chlorite (Chl) is coating on detrital grains and is associated with mixed-layer illite/smectite (Mix); primary pore (red arrow) is observed

or euhedral crystals. Ankerite cement also occurs as coatings occasionally enclosing the margins of quartz, feldspar, chert, rock fragments and also quartz overgrowths (Fig. 3E). Ankerite cement also occurs as a partial replacement of grains such as rock fragments (Fig. 3F).

Calcite. Calcite is absent in most samples but where it is present, it occurs in very minor amounts (0-27.2\%; Appendix 1). It is present as microcrystalline to coarse crystalline cement and may fill pore spaces (Fig. 5A). Grain-coating calcite on quartz and rock fragments is also recorded in the Narrabeen
Group. Minor calcite replacement of detrital grains occurs in most samples, particularly in the lower part of the Narrabeen Group. Fluid inclusions are uncommon in calcite cement and occur as scattered spheres.

Dolomite. Dolomite exists in all units of the Narrabeen Group (0-10.8\%; Appendix 1), although it occurs in trace amounts as anhedral to euhedral crystals (Fig. 5B). Thin sections showed the presence of dolomite as a replacement mineral in detrital grains in some samples. This technique also showed dolomite cement covering quartz, volcanic rock frag- 
ments and quartz overgrowths (Fig. 5B). Dolomite is also found as a pore-filling cement (Fig. 5B).

Authigenic feldspars. Alteration of feldspars is observed in the Narrabeen Group (Fig. 5C); occurring most commonly in volcanic rock fragments (Sur et al., 2002). In the present study albitisation of feldspar is also observed in the Narrabeen Group.

\section{DIAGENETIC SEQUENCE}

In the Narrabeen Group, diagenetic sequences are composed of early and late stages.

Compaction. Mechanical and chemical compaction was recorded in the Narrabeen Group. Mechanical compaction is more common than chemical compaction in the succession. Mechanical compaction is demonstrated by deformation of ductile grains and mica flakes between harder grains and by grain arrangement (Fig. 5D) and is more widespread in sandstone rich in detrital lithic grains than in sandstone rich in detrital quartz. Early authigenic clay minerals and carbonate cement prevent some mechanical compaction. However, detrital lithic grains are also affected by dissolution and alteration as well as mechanical compaction. Mechanical compaction is the main factor in the porosity reduction in the Narrabeen Group. Chemical compaction is evidenced by concavo-convex, sutured contacts and long grain contacts with rare pressure solution in the Narrabeen Group. Compaction occurred during both the early and late stages of diagenesis.

Authigenic clay minerals. Authigenic clay minerals, including kaolinite, mixed-layer illite/smectite, illite and chlorite are early authigenic minerals in the Narrabeen Group (Bai, 1991; Bai and Keene, 1996). The early formation of authigenic clay minerals is evidenced through the presence of clay minerals as grain coatings on detrital grains and as pore-filling cement (Fig. 4A-F).

Margins of many large pores are partly coated by kaolinite. Thus, grain-coating kaolinite and pore-filling kaolinite support the interpretation that kaolinite was formed during early diagenesis. Also, the occurrence of kaolinite in the form of vermicular texture supports this interpretation (cf. Wilkinson et al., 2004; Abouessa and Morad, 2009). Detrital grains such as feldspar are commonly coated by mixed-layer illite/smectite, indicating that illite and mixed-layer illite/smectite are early diagenetic in origin. Mixed-layer illite/smectite is present as coatings on authigenic kaolinite indicating that mixed-layer illite/smectite post-dates kaolinite. Authigenic chlorite is interpreted as an early diagenetic mineral, evidenced by pore-filling chlorite and grain-coating chlorite.

According to Bai (1991), precipitation of clay minerals, particularly kaolinite and mixed-layer illite/smectite, occurs from pore water under oxygenated and mildly acidic conditions. Also, early alteration of unstable detrital grains led to the formation of kaolinite and mixed-layer illite/smectite (Bai, 1991; Fig. 5E). Precipitation of kaolinite occurs from low $\mathrm{pH}$ and low ionic strength waters (Bjorlykke et al., 1986, 1989; Worden and Burley, 2003; Hammer et al., 2010). Replacement of feldspar may also contribute to the formation of illite (Umar et al., 2011) and, also high $\mathrm{K}^{+}$ions support the precipitation of illite (Bai, 1991). In the Narrabeen Group, dissolution and alteration processes led to the precipitation of clays which occur as grain-coating on surfaces of carbonate grains (Fig. 4C; Bai, 1991).

During burial diagenesis, the conversion of kaolinite into dickite is observed in the form of vermicular stacks and booklets of kaolinite along with thick to blocky dickite (Ehrenberg et al., 1993; McCaulay et al., 1994; Morad et al., 1994; Lanson et al., 2002; Abouessa and Morad, 2009). Two factors are important in the conversion of kaolinite into dickite: dissolution and re-pre- cipitation (Morad et al., 1994; Abouessa and Morad, 2009). The conversion of kaolinite into dickite occurs at temperatures $>100^{\circ} \mathrm{C}$ (Ehrenberg et al., 1993; McCaulay et al., 1994; Morad et al., 1994; Lanson et al., 2002; Abouessa and Morad, 2009).

In the Narrabeen Group, the precipitation of grain-coating chlorite and pore-filling chlorite cement occurred from pore water according to Bai (1991) who showed that anoxic and neutral to mildly alkaline pore-waters are the source for the precipitation of chlorite. Temperatures for growth of chlorite are about $60-70^{\circ} \mathrm{C}$ (Worden and Morad, 2003). In the Narrabeen Group, Bai (1991) indicated that alteration of framework grains such volcanic rock fragments are significant in the formation of chlorite. Umar et al. (2011) suggested that Mg, Fe and $\mathrm{Si}$ ions are important in the formation of chlorite in secondary pores, which result from dissolution of volcanic rock fragments. The precipitation of $\mathrm{Mg}$ and $\mathrm{Fe}$ ions may be recorded in early diagenetic chlorite (Sur et al., 2002) and this supports that pore-filling chlorite and chlorite grain coatings are early diagenetic.

Carbonate cement. Carbonate cement fills large pores in most samples indicating its early diagenetic formation (Figs. $3 \mathrm{C}-\mathrm{F}$ and $6 \mathrm{~B}, \mathrm{~B} 1)$. It was precipitated after some of the authigenic clays such as illite and kaolinite. Some detrital framework grains occur floating within the carbonate cement which also indicates its early precipitation. The precipitation of carbonate cement as grain-coatings on quartz, feldspar and rock fragments also supports the early formation of carbonate cement (Fig. 3C-F). Also, the replacement of detrital grains by carbonate cement supports this interpretation. In the Narrabeen Group, sandstone commonly shows loose grain packing and sandstone rich in carbonate cement is characterized by the presence of unformed ductile grains. Both these features confirmed the early diagenetic stage of carbonate cementation (cf. Salem et al., 2000). Also, euhedral siderite crystals, filling large pore spaces (Fig. 3C) can be interpreted as early diagenetic siderite. The occurrence of calcite in the form of large and poikilotopic crystals (Fig. 3F) support the interpretation of early diagenetic calcite (cf. Lee and Lim, 2008).

The relative concentrations of $\mathrm{Ca}^{2+}, \mathrm{Fe}^{2+}, \mathrm{Mg}^{2+}$ and $\mathrm{Mn}^{2+}$ in pore water contributes to the determination of the type of carbonate cement. Siderite or ankerite crystallised where high concentrations of $\mathrm{Fe}^{2+}$ are present, whereas the occurrence of non-ferroan calcite is associated with low $\mathrm{Fe}^{2+}$ and high $\mathrm{Ca}^{2+}$ (Bai, 1991). Also, Bai (1991) showed the important factors that support siderite formation include negative Eh, low calcium ion activity, low sulphide ion concentration, high carbon dioxide and high ferrous ion activity. Raised precipitation temperatures for siderite are supported by high $\mathrm{Mg}$ and low Ca which are characteristic in siderite cement (Abouessa and Morad, 2009). Also, high $\mathrm{Fe} / \mathrm{Ca}$ supports the interpretation of the precipitation of siderite cement within the early stage of diagenesis (Berner, 1981; Lee and Lim, 2008). Also, geochemical studies such as Estupinan et al. (2007) in fluvial environments showed that the precipitation siderite as an early diagenetic mineral is compatible with a low Sr content. Other authors (e.g., Mozley, 1989; Morad, 1998; Morad et al., 2000; Estupinan et al., 2007) indicated the precipitation of siderite during early diagenesis in fluvial environments is characterized by high $\mathrm{FeCO}_{3}$ and low $\mathrm{MnCO}_{3}$.

Dissolution/alteration of unstable detrital grains. Dissolution/alteration of unstable detrital grains occurred during the mid to late stage of diagenesis. Dissolution processes are indicated by secondary pore space, silica dissolution, feldspar dissolution, lithic fragment dissolution and carbonate dissolution (Fig. 6A, A1, B, B1). Secondary porosity is created as a result of dissolution of feldspar, carbonate cement and lithic grains (Fig. $6 \mathrm{~A}, \mathrm{A1}, \mathrm{B}, \mathrm{B} 1)$. The presence of $\mathrm{CO}_{2}$ in the groundwater led to the formation of dissolution porosity in the Narrabeen Group. 

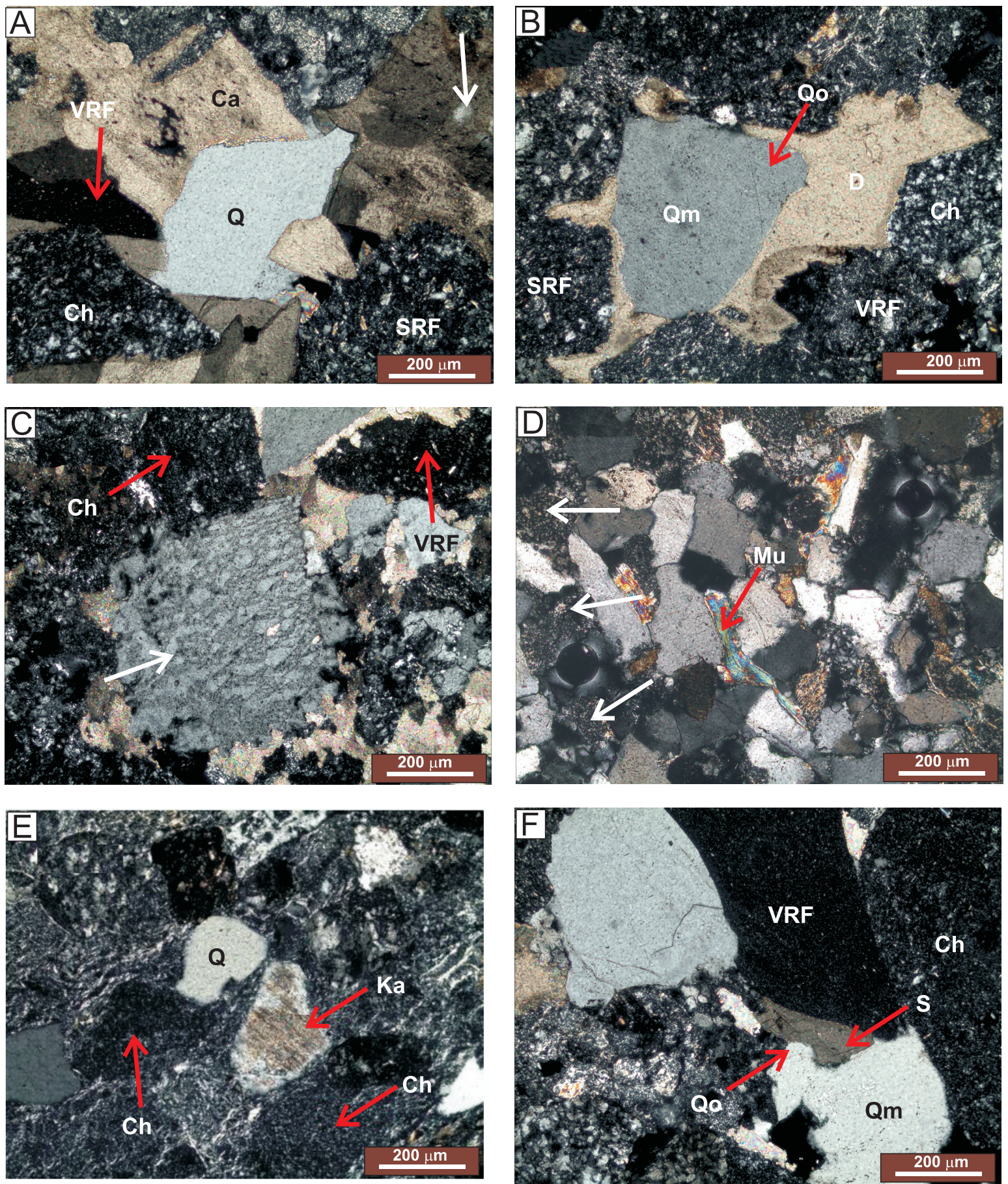

Fig. 5A - early coarsely crystalline calcite $(\mathrm{Ca})$ cement was precipitated around detrital quartz $(\mathrm{Q})$ and volcanic rock fragment (VRF) and replaced a detrital grain (white arrow); B - quartz overgrowth (Qo), monocrystalline quartz (Qm), chert (Ch) and rock fragment (VRF, SRF) grains are coated by microcrystalline dolomite (D) cement which also fills pores; C - altered feldspar (white arrow) plus carbonate cement that occurs as a coating on detrital grains such chert (Ch) and volcanic rock fragment (VRF); D - deformation of muscovite (Mu) between quartz grains indicates mechanical compaction; chert grains (white arrows) are present; $\mathrm{E}$ - kaolinite (Ka) is generated from dissolution of feldspar; $\mathrm{F}$ - late diagenetic siderite (S) cement precipitated on quartz overgrowth (Qo), monocrystalline quartz (Qm) and volcanic rock fragment (VRF); chert grain (Ch) is observed

Meteoric water and the maturation of organic matter are the source for the $\mathrm{CO}_{2}$ (Bai, 1991). Dissolution processes are followed by alteration of unstable detrital grains (Bai, 1991). In some samples, feldspar dissolution is associated with replacement by authigenic cement.
Alteration of unstable detrital grains led to the formation of kaolinite + quartz, or illite + quartz or authigenic kaolinite (Bai, 1991). This also happened under acidic conditions.

Authigenic feldspar precipitation occurred during mid to late stage diagenesis in the Narrabeen Group as indicated by the alteration of feldspar. Thus, the dissolution of detrital 
K-feldspar is the main origin of authigenic K-feldspar (cf. Wolela, 2009). Factors that contribute to K-feldspar precipitation include high silica activities and high $\mathrm{K}^{+} / \mathrm{H}^{+}$ratios as indicated by (Morad et al., 2000).

Authigenic quartz. Quartz overgrowths represent a mid to late authigenic mineral in the Narrabeen Group, occurring as a pore-filling cement (Figs. 3A and 4A). Some stacked kaolinite flakes are enclosed by quartz overgrowths, which also engulf authigenic carbonate crystals. These features indicate that quartz overgrowths post-date carbonate cementation and the authigenic clay minerals. Bai (1991) confirmed that the late formation of quartz overgrowths is indicated by aqueous fluid inclusions in the quartz overgrowth which have an average homogenisation temperature of $90-120^{\circ} \mathrm{C}$.

Detrital quartz grains are the source of silica in the Narrabeen Group, thus lithic-rich sandstones only contain rare quartz overgrowths (Bai and Keene, 1996). Also, early compaction is the reason for the absence of pore spaces, preventing circulation of pore fluids (Sur et al., 2002). The silica for the quartz overgrowths was derived from pressure solution indicated by sutured contacts between quartz grains. According to Zhang et al. (2010) the occurrence of quartz overgrowths with kaolinite shows that quartz cement may be sourced from silicon dioxide through feldspar dissolution.

Umar et al. (2011) indicated that alternative sources of silica for quartz cementation are the dissolution of feldspar and volcanic rock fragments, chloritization, kaolinitization and chemical compaction.

Late carbonate cements. Carbonate cementation occurred again after quartz overgrowths during late diagenesis. Siderite, ankerite and dolomite are all observed as pore-filling cements that partly coat quartz overgrowths in some samples (Fig. 5F). This indicates that siderite, ankerite and dolomite continued to be precipitated during late diagenesis. In other samples, late diagenetic carbonate cements are not present.

Discontinuous carbonate cement and oversized pores are created by dissolution of earlier carbonate cement (cf. Al-Harbi and Khan, 2008). Late carbonate cement such as siderite, ankerite and dolomite may be formed as new carbonate cements in some samples after dissolution of early carbonate cement (Fig. 6B, B1; cf. Chi et al., 2003).

Late authigenic clays. After quartz overgrowths, illite was precipitated again and coats some quartz overgrowths (Fig. $4 \mathrm{~A})$. Mixed-layer illite/smectite was also precipitated as grain coatings on quartz overgrowths and carbonate cement (Fig. $4 A, C)$. Chlorite and kaolinite also occur later and coat quartz overgrowth. This evidence indicates that some mixed-layer illite/smectite, illite and kaolinite post-date the quartz overgrowths and carbonate cement. These precipitations indicate the late formation of some authigenic clay minerals. Detrital inheritance from K-, Ca- and Mg-rich silicates under alkaline conditions suggests the precipitation of mixed layer illite/smectite and chlorite as late stage diagenetic minerals after the development of quartz overgrowths.

In conclusion, the chronological order of the diagenetic phases is as follows:

- mild compaction;

- formation of authigenic clays;

- precipitation of carbonate cement;

- silica dissolution, feldspar dissolution, rock fragment dissolution and carbonate cementation dissolution;

- secondary silica overgrowths;

- late carbonate cement;

- late authigenic clay minerals.

\section{POROSITY DATA}

In the present study, porosity ranges from 0 to $19.5 \%$ (Appendix 1 ) at average of $5.4 \%$ in the sandstone whereas it is absent in the siltstone samples. Secondary porosity is more common than primary porosity in all units of the Narrabeen Group.

Primary porosity. In the Narrabeen Group, primary porosity reaches $3.7 \%$ in sandstone samples (Appendix 1) but it is absent in siltstone samples (Figs. 4A, B and 6C, C1). It occurs in sandstone at an average of $0.7 \%$.

Secondary porosity. Secondary porosity does not exceed $18 \%$ in the Narrabeen Group (Appendix 1) at an average of $4.7 \%$ in sandstone by petrographic point count. The size of secondary porosity was determined to range from 24 to $246 \mu \mathrm{m}$, depending on grain size. This means that pore size and grain size are often similar.

In the Narrabeen Group, intergranular porosity, intragranular porosity, mouldic pores and oversized pores are also observed. Intergranular porosity is present as result of dissolution of porefilling carbonate cement and ranges from 34 to $211 \mu \mathrm{m}$ in size (Fig. 6B, B1). However, intragranular porosity exists mostly as a result of partial or complete dissolution of feldspar and volcanic rock fragments (Fig. 6A, A1; Mansurbeg et al., 2008) and varies in size between 45 and $199 \mu \mathrm{m}$. Mouldic pores are observed in both coarse- and fine-grained sandstone but are more common in coarse-grained beds. In the Narrabeen Group, it mainly occurs due to the partial dissolution of plagioclase with sizes between 31 and $234 \mu \mathrm{m}$. Also, dissolution of detrital grains such feldspar can result in oversized pores in sandstones with size ranges from 65 to $244 \mu \mathrm{m}$ (Lima and De Ros, 2002). Connectivity is shown in this unit by mouldic and oversized pores. Corroded traces of feldspar occur in both mouldic pores and oversized pores. Also, packing inhomogeneity and honeycombed grains are observed in secondary pores.

\section{INFLUENCE OF DIAGENETIC ALTERATION AND COMPOSITION ON RESERVOIR QUALITY}

\section{COMPACTION}

In the Narrabeen Group, compaction has the greatest influence on thin section porosity. Thus, porosity loss in the Narrabeen Group is high as result of both mechanical (e.g., Higgs et al., 2007; Dutton and Loucks, 2009) and chemical compaction (cf. Higgs et al., 2007). According to Ramm (1992) the poor sorting and common detrital clays contribute to the porosity loss through mechanical compaction.

In sandstone rich in detrital lithic fragments, chemical and mechanical compaction is observed and reduces porosity (cf. Tobin et al., 2010). In these samples, deformation of ductile grains and mica between quartz grains illustrates porosity reduction by mechanical compaction (Fig. 5D). Deformation of lithic fragments is common in the Narrabeen Group, resulting from mechanical compaction, and plays a major role in porosity loss (cf. Buyukutku and Sahinturk, 2005). Ductile grains are common in all units and they account for the low porosity in most samples, as shown by Gier et al. (2008). Alteration, extension of detrital mica and intergranular pressure dissolution of quartz grains caused additional porosity loss in the Narrabeen Group (cf. Hlal, 2008; Fig. 5D). The effect of mechanical compaction on porosity occurs during early burial and is more effective in the absence or rarity of carbonate cement in some samples of the Coalcliff Sandstone and Scarborough Sand- 

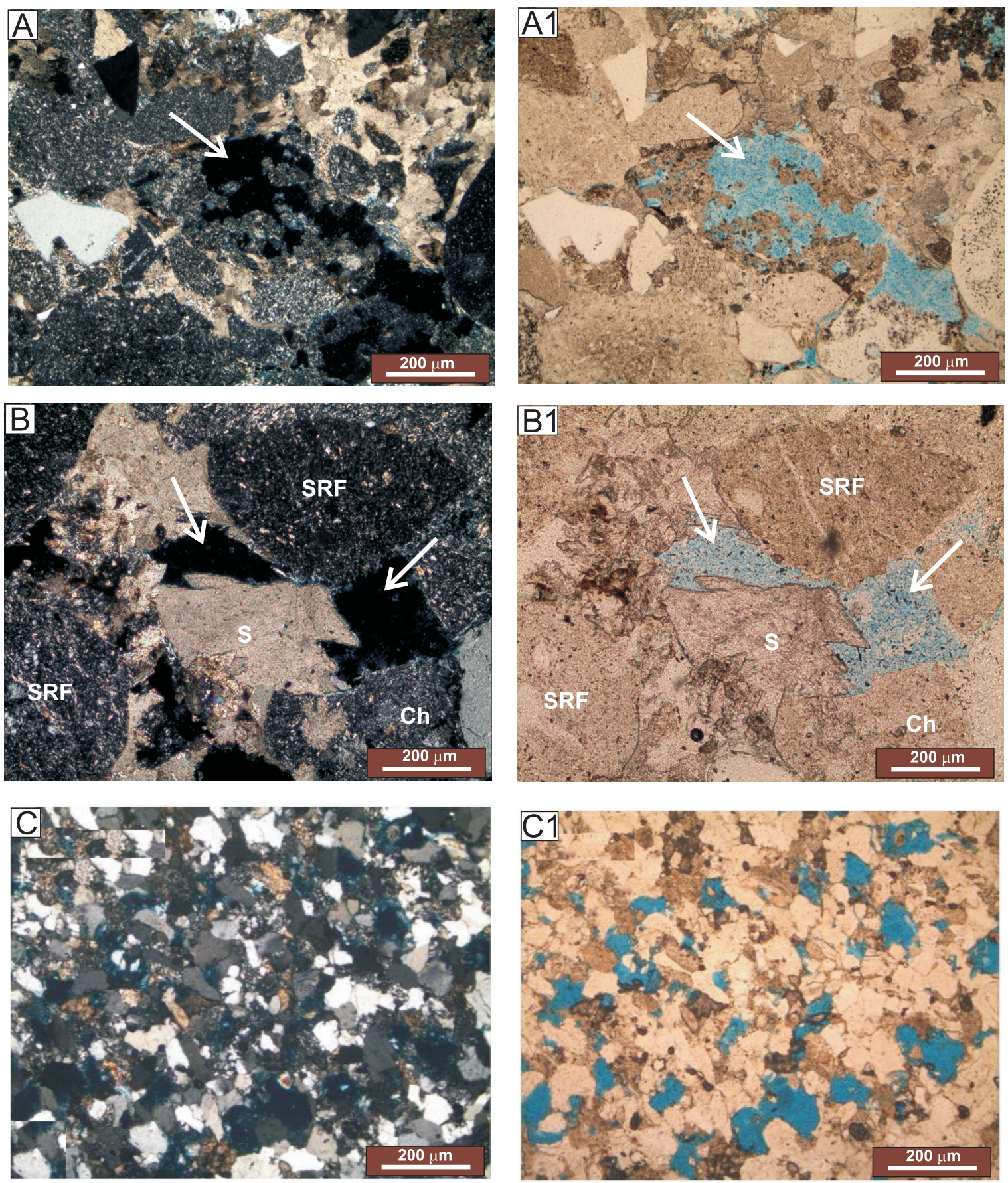

Fig. 6A, A1 - secondary porosity (white arrow) occurs within a partially dissolved lithic grain, margins of detrital grains such as quartz and chert are coated by dolomite cement; B, B1 - secondary porosity (white arrows) result from dissolution of siderite (S) cement, margins of sedimentary rock fragment (SRF) and chert (Ch) grains are coated by siderite cement; C, C1 - primary pores occur between grains

stone as shown by Umar et al. (2011). In some units of the Narrabeen Group, clays predominate over quartz grains and porosity is almost entirely lost as result of mechanical compaction (cf. Ehrenberg et al., 2008). These factors indicate a strong relationship between sandstone composition and porosity. Chemical compaction is also significant to reduce porosity through the interpenetration of grains in the lithic-rich sandstone. The preservation of porosity is reduced by long, concavo-convex and sutured contacts that represent chemical compaction. In samples with little carbonate cement, chemical compaction continues to obliterate porosity and is more effective (cf. Kim and Lee, 2004). In the Narrabeen Group, secondary porosity was developed in some sandstone samples before compaction ended. In this study, any secondary pores that developed were compacted, thus secondary porosity was absent in some of thin section because of compaction (Kim and Lee, 2004). The amount of porosity reduced by mechanical and chemical compaction in the Narrabeen Group is similar to that in the Illawarra Coal Measures and these losses are not unrecoverable (cf. Wolela, 2009). Pseudomatrix occurs as result of mechanical compaction and fills both small and large pores, thus further reducing porosity as shown 
by El-Ghali et al. (2009). Pseudomatrix is often more important for porosity reduction where lithic grains are absent in the Narrabeen Group (cf. Al-Ramadan et al., 2004). Grain rearrangement is also an important porosity reduction factor in the absence of lithic grains, particularly in quartzose samples (Worden et al., 2000). Porosity in fine-grained deposits is mainly reduced by mechanical compaction (e.g., Mansurbeg et al., 2008).

In the sandstone rich in detrital quartz, pore spaces are preserved because mechanical compaction is prevented by the detrital grain framework. This suggests that the influence of mechanical compaction on porosity was less in this type of sample (Abouessa and Morad, 2009). Thus, in the Bulgo Sandstone, the effect of compaction on primary porosity is less due to the quartz-rich nature of parts of the unit, as shown by Smosna and Sager (2008). This unit is characterized by a low abundance of ductile grains, thus compaction is inhibited due to rigid grains which support the stable framework grains, preserving primary porosity (cf. Sager, 2007). Thus, about $12 \%$ of primary porosity occurs in this unit.

\section{CARBONATE CEMENTATION}

Carbonate cement has the influence on thin section porosity after the influence of compaction in the Narrabeen Group. The relationship between porosity and carbonate cement in the samples shows that when the porosity is less than $2 \%$ carbonate cement is more than $20 \%$, whereas when the porosity is more than $15 \%$, carbonate cement does not exceed $5 \%$. This suggests that carbonate cement significantly affects both sandstone rich in detrital lithic grains and sandstone rich in detrital quartz (e.g., Wolela and Gierlowski-Kordesch, 2007; Luo et al., 2009; Hammer et al., 2010).

In sandstone rich in detrital lithic fragments and sandstone rich in detrital quartz, early carbonate cement fills both large and small pores and reduces the primary porosity, as shown by Umar et al. (2011). The widespread early carbonate cement may completely fill the pores, but even minor early carbonate cement can support the framework grains against compaction. All types of carbonate cement, including ankerite, siderite, dolomite and calcite, are observed under the microscope as porefilling cement, has reduced the primary porosity in the Narrabeen Group (Figs. 3C-F and 5B). Ankerite cement has the most influence on thin section porosity, followed by siderite cement. In a similar study, El-Ghali et al. (2009) showed that carbonate cement, represented by calcite and dolomite, destroyed porosity in the Early Triassic Petrohan Terrigenous Group in north-west Bulgaria. In the present study, porosity in sandstone rich in detrital lithic grains is influenced more by carbonate cement than sandstone rich in detrital quartz.

In the Narrabeen Group, porosity loss due to carbonate cement may be recoverable in both lithic-rich and quartzose sandstone. Early carbonate cement contributes to the preservation of porosity by:

1. Preventing the development of quartz cement and early mechanical compaction. In this case the framework is supported against mechanical compaction by early carbonate cement that also prevents porosity loss due to quartz cement.

2. Carbonate cement may be dissolved during later diagenesis, forming secondary porosity (e.g., Chi et al., 2003; Zhang et al., 2007; Fig. 6B, B1).

However, where early cementation was abundant and almost completely occluded primary porosity, later dissolution was compensated by re-precipitation of calcite and no new po- rosity was created. New porosity was only generated if the dissolution of this early calcite cement was not compensated by new cement formation.

Also, incomplete pore-filling by carbonate cement supports the preservation of porosity in some samples. Later dissolution of carbonate cement can be observed and result in carbonate cement partly filling pores (Fig. 6B, B1). This process was often seen in sandstone rich in detrital quartz. In other cases, carbonate grains can be effective in the preservation or destruction of porosity - they may dissolve and result in secondary porosity or they are dissolved and then re-precipitated as carbonate cement (cf. Hlal, 2008).

\section{AUTHIGENIC CLAY MINERALS}

In the Narrabeen Group, porosity is commonly reduced by authigenic clay minerals (cf. Zhang et al., 2008) and such porosity is unrecoverable in this succession. Although the influence of authigenic clays on porosity is effective, it had less influence than compaction and carbonate cement. Scanning electron microscope studies showed the types of pore-filling authigenic clay minerals which reduce primary porosity in the Narrabeen Group (cf. Wolela and Gierlowski-Kordesch, 2007). Vermicular booklets of kaolinite occur as pore-fillings and cause significant porosity loss (Fig. 4B). Deformed kaolinite occurs as pseudomatrix that effectively decreases porosity in the Narrabeen Group. Chlorite has been observed by scanning electron microscope in both primary and secondary pores and it also causes loss of porosity in the Narrabeen Group. Also, porosity is decreased by pore-filling illite and mixed-layer illite-smectite in sandstones units (cf. Al-Ramadan et al., 2004). Pore-filling illite and mixed-layer illite/smectite have a greater influence on porosity loss in lithic-rich sandstone whereas pore-filling kaolinite and chlorite cause the greatest porosity loss in quartz-rich sandstone. This comparison depends on the results of scanning electron microscope and X-ray diffraction analyses.

Grain-coating clays, represented by chlorite, illite and mixed layer illite/smectite, help to preserve porosity in the Narrabeen Group in both lithic-rich and quartz-rich sandstone. In similar studies, Salem et al. (2005) showed that porosity is preserved in the Abu Madi Gas reservoirs in the Nile Delta Basin in Egypt because of the role of grain-coating clays that inhibit the growth of quartz overgrowths.

In the present study, grain-coating clays effectively inhibit the precipitation of quartz overgrowth cement, thus low porosity may be preserved in parts of the Narrabeen Group. Mixed layer illite-smectite is observed as a grain-coating on quartz overgrowths in many samples (Fig. 4A). This indicates that low porosity is still present in the Narrabeen Group. Also, small quantities of grain-coating chlorite inhibit quartz overgrowths and increase the percentage of preserved porosity in the Narrabeen Group (e.g., Baker et al., 2000; Salem et al., 2005; Umar et al., 2011). Grain-coating illite clays are present in the Narrabeen Group around quartz overgrowths. Thus, they contribute to the preservation of porosity in these deposits (cf. Storvoll et al., 2002; Mansurbeg et al., 2008; Abouessa and Morad, 2009). This supports the abundance of quartz overgrowths in sandstone that has low grain-coating clays. Grain-coating mixed layer illite-smectite plays the greatest role in the preservation of porosity because it is more common than grain-coatings of illite or chlorite. Also, the illite-smectite coatings are thicker and more continuous than other grain-coating clays. They have the ability to prevent the growth of quartz cement during burial and thus retain porosity (e.g., Bloch et al., 2002; Islam, 2009; Luo et al., 2009). No 
grain-coating kaolinite was observed around quartz overgrowths in this succession. In sandstones, the opposite occurs between clay coatings and porosity in the absence of compaction. In some units, particularly in quartz-rich sandstone, grain-coating clays that occur as thin or discontinuous layers are not significant in preventing the development of quartz overgrowths. Thus, porosity was not observed in these units. The development of quartz cement is less affected by detrital clay rims than by authigenic clay coatings which are more continuous in the Narrabeen Group (Taylor et al., 2010). Detrital clay rims are generated by mechanical infiltration (Taylor et al., 2010).

\section{DISSOLUTION}

In the Narrabeen Group, feldspar, rock fragments and carbonate cement were dissolved in some samples during mid to late diagenesis leading to the enhancement of porosity (cf. Chi et al., 2003). Secondary porosity occurs in all units of the Narrabeen Group as a diagenetic feature resulting from dissolved grains. Dissolution of feldspar is supported by the presence of secondary porosity in the Narrabeen Group, particularly in the Coalcliff Sandstone (e.g., Baker et al., 2000; Salem et al., 2000; Lima and De Ros, 2002; El-Ghali et al., 2006; Zhang et al., 2007, 2008; Abouessa and Morad, 2009; Hammer et al., 2010). Also, Luo et al. (2009) showed a similar influence of dissolution of plagioclase in the enhancement of secondary porosity in the Ordos Basin in China. In the present study, plagioclase grains were more likely to be dissolved than K-feldspar grains, thus the former is more effective in forming secondary porosity in the Narrabeen Group. Lithic-rich sandstone in the Coalcliff Sandstone and Scarborough Sandstone shows lithic grain dissolution resulting in secondary porosity (cf. Ketzer et al., 2003; Islam, 2009; Fig. 6A, A1). In the Bulgo Sandstone, most of the lithic grains are dissolved, thus it contains more secondary porosity. Volcanic rock fragments are more abundant and less stable than sedimentary rock fragments, thus they are of greater importance in the formation of secondary porosity. Dissolution of unstable grains is volumetrically subordinate in the Narrabeen Group, similar to the Illawarra Coal Measures, indicating the role of composition to support porosity by dissolution of feldspar and lithic detrital grains. Carbonate cement is also dissolved in the Narrabeen Group forming secondary porosity, particularly in the Coalcliff Sandstone and Wombarra Claystone (cf. Al-Ramadan et al., 2004; Zhang et al., 2010; Fig. 6B, B1). However, dissolution of unstable grains is more common and more important than dissolution of carbonate cement in the Narrabeen Group. The development of secondary porosity post-dates quartz overgrowths and carbonate cement in the Narrabeen Group as indicated by the presence of oversized pores and corroded grain boundaries, including corrosion of quartz overgrowths and carbonate cement. Determining the amount of secondary porosity that formed by dissolution of carbonate cement is difficult in some samples. On the contrary, it is easy to identify secondary porosity formed by dissolved unstable grains.

In some cases, the dissolution of grains such as feldspar may not contribute to the development of much porosity in the Narrabeen Group for two reasons. Firstly, the solution porosity may occur inside the feldspar grain forming minor intragranular porosity (cf. Zhang et al., 2007). Secondly, secondary pores generated by dissolution of feldspars may be filled by carbonate cement (cf. Umar et al., 2011) and/or authigenic kaolinite (cf. Bertier et al., 2008) in some samples. These reasons are enough to prevent the development of much secondary porosity that is formed by the dissolution of feldspar grains. Also, mechanical compaction may cause the collapse of the secondary porosity after dissolution in the Narrabeen Group, similar to the Illawarra Coal Measures (Wilkinson et al., 2001; Dutton and Loucks, 2009).

Several factors play a role in the dissolution of grains and cements that form secondary porosity. These are organic acids, $\mathrm{CO}_{2}$ and dehydration of clay minerals (Zhang et al., 2007) in addition to inorganic mineral and meteoric water reactions (Chi et al., 2003). Dissolution may occur as a result of the original pore fluids but is more commonly associated with acidic ground water invasion (e.g., Al-Hajri et al., 1999; Al-Ramadan et al., 2004). Pore fluid is also important in the dissolution of carbonate cement, such as calcite cement (McBride et al., 1996).

The importance of dissolution of grains and cements in the production of secondary porosity in the Narrabeen Group is greater than in the Illawarra Coal Measures, even though lithic and feldspar grains are more common in the Illawarra Coal Measures. This may be due to more abundant circulation of meteoric water in the Narrabeen Group (e.g., Mansurbeg et al., 2008).

\section{QUARTZ OVERGROWTHS}

In the Narrabeen Group, thin section porosity is reduced by quartz overgrowths but they are rare. In fact, in the Narrabeen Group a very low positive correlation is recorded between quartz overgrowths and thin section porosity. In lithic-rich sandstone, the abundance of carbonate cement and ductile grains reduces the influence of quartz overgrowths on porosity. Quartz overgrowths mainly occur in cleaner sandstone and hence they have a moderate positive correlation with thin section porosity in the Scarborough Sandstone. This means that when quartz overgrowths are present, they may further reduce physical and chemical compaction and preserve more primary porosity. Thus, the influence of compaction on porosity may be reduced by minor quartz overgrowths, preserving porosity in some samples (cf. Abouessa and Morad, 2009). Also, in lithic-rich sandstone, quartz overgrowths have a low negative correlation with porosity. Here minor pore spaces are filled with quartz overgrowths further reducing porosity (cf. Molenaar et al., 2007). Grain-coating clays around detrital quartz grains are common in the lithic-rich sandstone, as indicated by scanning electron microscope studies (Fig. 4A). This process prevents the development of quartz overgrowths, thus some primary porosity is preserved (e.g., Islam, 2009; Salem et al., 2005).

In quartz-rich sandstone, quartz overgrowths contribute to the reduction of thin section porosity (cf. Islam, 2009; Fig. 4A). They are present as pore-filling cement that reduces primary porosity. Also, early carbonate cements are uncommon in these samples; consequently quartz overgrowths effectively decrease primary porosity. Quartz cement also inhibits further compaction and fills pore space between grains, thus porosity is reduced in quartz-rich sandstone (cf. Zhang et al., 2010). Primary porosity is more influenced by quartz overgrowths due to the lack of ductile grains and carbonate cement in quartz-rich sandstone.

In these samples, grain coating clays are also present and can control the evolution of quartz overgrowths, preserving porosity particularly in the Bulgo Sandstone (cf. Islam, 2009; Salem et al., 2005). 


\section{RESERVOIR POTENTIAL OF THE SOUTHERN SYDNEY BASIN}

Mullard (1995) showed that the Stanwell Park Claystone, Bald Hill Claystone and Wombarra Claystone would be good seals in the Narrabeen Group. In this study, porosity is low in the Stanwell Park Claystone, Bald Hill Claystone and Newport Formation. Shale and siltstone beds are dominant in these formations and they are poorly sorted and fine-grained. Thus, they have low porosity. Siderite, ankerite, kaolinite and mixed layer illite/smectite are present and reduce porosity in these formations. The factors including lithology, sorting, grain size and diagenetic alteration reduce porosity, and thus the pore space available for hydrocarbon occurrences is low. This indicates that the Stanwell Park Claystone, Bald Hill Claystone and Newport Formation are very poor reservoirs but are good seals in the Narrabeen Group.

The environment of deposition in the Coalcliff Sandstone, Scarborough Sandstone and Bulgo Sandstone was fluvial and is not very different from the environments of many other typical fluvial groundwater and hydrocarbon reservoirs. The Coalcliff Sandstone, Scarborough Sandstone and Bulgo Sandstone contain medium- and coarse-grained sandstone, shale and siltstone. Medium- and coarse-grained sandstone are more common than shale and siltstone in these formations and are moderately to well sorted with rounded to sub-rounded grains. They have low to moderate thin section porosity which is higher in the Bulgo Sandstone than in the Coalcliff Sandstone and Scarborough Sandstone. Thus, these formations are poor to moderate reservoirs and probably contain gas or water (Wolela, 2009). Also, Mullard (1995) indicated that these formations could be hydrocarbon reservoirs in the Narrabeen Group. There are potential barriers to reduce the occurrence of gas or water in the medium- and coarse-grained sandstone. These are represented by mechanical compaction, carbonate cement, authigenic clays and quartz overgrowths. Mechanical compaction occurs commonly in these medium- to coarse-grained sandstones and reduces porosity. Carbonate cement, authigenic clays and quartz overgrowths also fill pore spaces and reduce porosity in the medium- and coarse-grained sandstone. Thus the pore spaces available for gas or water are probably low in these units as result of diagenetic alteration. Minor secondary porosity occurs as a result of dissolution of grains and may provide some pore spaces for gas or water in the medium- and coarse-grained sandstone. In the Adigrat Sandstone, Wolela (2009) showed that medium- to coarse-grained sandstone can be porous and permeable and may be characterized by the presence of oil and gas. Well logs showed the presence of porosity in the medium- to coarsegrained sandstone in this study. The Coalcliff Sandstone, Scarborough Sandstone and Bulgo Sandstone are rich in volcanic rock fragments which may form hydrocarbon traps according to Ryan (2005).

The associated shale and siltstone units have very low thin section porosity and consist of very fine poorly sorted grains in the Coalcliff Sandstone, Scarborough Sandstone and Bulgo Sandstone. Schoen (1996) showed that the preservation of primary porosity can be affected by grain size and sorting. Thus, these fine units represent poor reservoirs and are recognized as confining layers in these formations. Secondary clay minerals, particularly mixed layer illite/smectite, are common in the shale and siltstone units and prevent the preservation of porosity, thus pore spaces are unavailable for gas or water in these units. This indicates that the shale and siltstone beds form local seals in the Coalcliff Sandstone, Scarborough Sandstone and Bulgo Sandstone.
Shale, siltstone and sandstone are also observed in the Wombarra Claystone which is characterized by a dominance of shale units. Thin section porosity in the shale and siltstone units is further reduced by carbonate cement and clays, thus visible porosity is zero. The shale and siltstone units are also poorly sorted and fine-grained, thus porosity is very low in these units. This indicates that the shale and siltstone units form lithological seals and confining layers in the Wombarra Claystone. However, the few included sandstone beds have low thin section porosity and are more porous than the shale or siltstone units. The sandstone beds are moderately to well sorted with rounded to sub-rounded grains. This indicates that the sandstone beds could support gas or water resources in the Narrabeen Group (Wolela, 2009). The influence of diagenetic alteration on reservoir quality can affect hydrocarbon occurrences in sandstone beds. Pore-filling carbonate cement, particularly siderite and ankerite, is present in the sandstone beds and causes additional porosity loss. Authigenic clays are also present as porefilling cements and they also cause a loss of porosity. These factors reduce the pore spaces available for gas or water in sandstone beds.

The Bulli Coal underlies the Coalcliff Sandstone and is a source of gas in the Narrabeen Group. Ryan (2005) confirmed that the Illawarra Coal Measures may be the source for gas in the Narrabeen Group, providing evidence that gas in the Coalcliff Sandstone and in the coal measures has a similar composition. In this study, the base of the Coalcliff Sandstone contains porous beds. Thus, gas probably migrated through these beds to the upper parts of the Coalcliff Sandstone.

The migration of gas or movement of water may be affected by folds and faults in the Narrabeen Group. Synclines have been recorded as potential barriers to gas flow in the Narrabeen Group. Faults may be present as seals and break anticlinal reservoirs, thus they reduce the reservoirs in Narrabeen Group (Dickey, 1981). This may suggest that faults are important in the destruction of hydrocarbon reservoirs. In the Narrabeen Group groundwater movement is probably controlled by faults which can prevent free groundwater movement and form semi-isolated groundwater reservoirs. This indicates that the presence of faults probably changed the path of groundwater migration in the Narrabeen Group.

\section{CONCLUSIONS}

The Narrabeen Group is litharenite and sublitharenite to rare quartzarenite. The Narrabeen Group plot in the lithic continental to transitional recycled and quartzose recycled provenance fields. A few samples from the Narrabeen Group plot in the craton interior field. In the Narrabeen Group, quartz and lithic grains are derived from the New England Fold Belt and an eastern volcanic arc with minor contributions from the Lachlan Fold Belt.

Petrographic data demonstrated that lithic grains are more common in the Narrabeen Group. Feldspar grains are sparse in the Narrabeen Group. Quartz includes monocrystalline and polycrystalline quartz grains whereas feldspar grains consist of K-feldspar and plagioclase. Rock fragments are volcanic or sedimentary. Mica includes more common muscovite than biotite. The heavy minerals comprise hematite, hornblende, rutile, zircon and tourmaline in trace percentages.

Thin section and scanning electron microscope analyses showed that carbonate cement is most common in the Narrabeen Group. Authigenic minerals included quartz overgrowths, authigenic clay minerals, carbonate cement, authigenic feld- 
spar, authigenic pyrite and iron oxide cement. Authigenic clay minerals are common, and are represented by kaolinite, illite, mixed-layer illite-smectite and chlorite. Quartz overgrowths are rare. Siderite, ankerite, calcite and dolomite are present as carbonate cements but siderite is dominant.

Secondary porosity is more common than primary porosity in the Narrabeen Group. The influence of mechanical compaction on thin section porosity is important. Carbonate cement is prevalent, thus it has an important influence on thin section porosity. Pore-filling clays are dominant and reduce thin section porosity in this unit. Also, grain-coating clays preserve thin section porosity in these units but their importance is greatest. Lithic and feldspar grains are common and secondary porosity caused by unstable grain dissolution is abundant.

The Wombarra Claystone contains common shale and siltstone and minor thin sandstone beds. Thin section porosity is absent in shale and siltstone units which form seals and confining layers. Thin section porosity occurs in the more porous sandstone beds in the Wombarra Claystone. These beds probably represent minor gas or water resources. Visible porosity is completely absent in the Stanwell Park Claystone, Bald Hill Claystone and Newport Formation. These formations include mainly shale and siltstone units which are poorly sorted and are characterized by abundant clays. Visible porosity is absent in shale and siltstone units since all intergranular spaces are filled with clay. Thus, the Stanwell Park Claystone, Bald Hill Claystone and Newport Formation are very poor reservoirs but represent good seals. On the other hand, the Coalcliff Sandstone, Scarborough Sandstone and Bulgo Sandstone are characterized by medium- and coarsegrained sandstone with only minor amounts of shale and siltstone. In these formations, the medium- and coarsegrained sandstone is moderately to well sorted and shows low to moderate thin section porosity. Thus, they represent poor to moderate reservoirs and probably contain gas or water. The Bulgo Sandstone contains the highest percentage of thin section porosity in the Narrabeen Group. Thus, the volume available for gas or water probably is the greatest in the Bulgo Sandstone. The Coalcliff Sandstone directly overlies the Bulli Coal, thus it may contains larger amounts of gas than in the Scarborough Sandstone and Bulgo Sandstone. Thus, coal seam gas in the Illawarra Coal Measures may be the source of gas in the Narrabeen Group.

Acknowledgements. This work was supported by the University of Wollongong. Samples were collected by BHPBilliton Illawarra Coal who provided samples from study area. Also, they supported me with well logs, maps and additional information. Thin sections, scanning electron microscope photos and $X$-ray diffraction analyses were completed by the laboratories in the University of Wollongong. I would like to thank the library staff in the University of Wollongong and the Geological Quarterly reviewers (A. Barczuk and an anonymous) for their help during the preparation of this paper.

\section{REFERENCES}

Abouessa A., Morad S. (2009) An integrated study of diagenesis and depositional facies in tidal sandstones: Hawaz Formation (Middle Ordovician), Murzuq Basin, Libya. Journal of Petroleum Geology, 32: 39-66.

Al-Hajri S.A., Filatoff J., Wender L.E., Norton A.K. (1999) Stratigraphy and operational palynology of the Devonian System in Saudi Arabia. GeoArabia, 4: 53-68.

Al-Harbi O.A., Khan M.M. (2008) Provenance, diagenesis, tectonic setting and geochemistry of Tawil Sandstone (Lower Devonian) in central Saudi Arabia. Journal of Asian Earth Sciences, 33: 278-287.

Al-Ramadan K.A., Hussain M., Imam B., Saner S. (2004) Lithologic characteristics and diagenesis of the Devonian Jauf Sandstone at Ghawar Field, eastern Saudi Arabia. Marine and Petroleum Geology, 21: 1221-1234.

Bai G.P. (1988) Diagenesis of the sandstones in the Narrabeen Group. Proceedings of the symposium on advances in the study of the Sydney Basin. Department of Geology, the University of Newcastle: $47-53$.

Bai G.P. (1991) Petrology, diagenesis and reservoir potential of Narrabeen Group sandstones, Sydney Basin. NSW. PhD thesis, University of Sydney, Sydney.

Bai G.P., Keene J.B. (1996) Petrology and diagenesis of Narrabeen Group sandstones, Sydney Basin, New South Wales. Australian Journal of Earth Sciences, 43: 525-538.

Baker G. (1956) Pelletal claystone from the Southern Coalfield, New South Wales, Australia. Journal of Science, 18: 126-127.

Baker J.C., Havord P.J., Martin K.R., Ghori K.A.R. (2000) Diagenesis and petrophysics of the Early Permian Moogooloo Sandstone, southern Carnarvon Basin, Western Australia. AAPG Bulletin, 84: 250-265.

Bamberry W.J. (1992) Stratigraphy and sedimentology of the Late Permian Illawarra Coal Measures, Southern Sydney Basin, New South Wales. PhD. thesis, University of Wollongong, Wollongong.
Berner R.A. (1981) A review geochemical classification of sedimentary environments. Journal of Sedimentary Petrology, 51: 359-365.

Bertier P., Swennen R., Lagrou D., Laenen B., Kemps R. (2008) Palaeo-climate controlled diagenesis of the Westphalian C \& D fluvial sandstones in the Campine Basin (north-east Belgium). Sedimentology, 55: 1375-1417.

Bjorlykke K., Aagaard P., Dypvik H., Hastings D., Harper A. (1986) Diagenesis and reservoir properties of Jurassic sandstones from the Haltenbanken area, offshore mid-Norway, Norwegian Petroleum Society. In: Habitat of Hydrocarbons on the Norwegian Continental Shelf (ed. A. Spencer): 275-286. Norwegian Petroleum Society. Graham and Trotman.

Bjorlykke K., Ramm M., Saigal G. (1989) Sandstone diagenesis and porosity modification during basin evolution. International Journal of Earth Sciences, 68: 1151-1171.

Bloch S., Lander R.H., Bonnell L. (2002) Anomalously high porosity and permeability in deeply buried sandstone reservoirs: origin and predictability. AAPG Bulletin, 86: 301-328.

Bowman H.N. (1974) Geology of the Wollongong, Kiama and Robertson 1: 50,000 sheets. Geological Survey New South Wales, Sydney, Sydney.

Bowman H.N. (1980) Southern Coalfield, upper Shoalhaven Group and Illawarra Coal Measures. Geological Survey of New South Wales, Bulletin 26: 117-132.

Bunny M.R. (1972) Geology and coal resources of the Southern catchment coal reserve, southern Sydney Basin, New South Wales. Geological Survey of New South Wales, Bulletin, 22.

Bunny M.R., Herbert C. (1971) The lower Triassic Newport Formation, Narrabeen Group, southern Sydney Basin. Records of the Geological Survey of New South Wales, 13: 61-81.

Buyukutku A.G., Sahinturk O. (2005) The diagenesis of the upper Oligocene and Mio-Pliocene sandstones and its relevance to hydrocarbon exploration in the East Anatolia Basin, Turkey. Journal Geological Society of India, 65: 468-478. 
Carr P.F. (1983) A reappraisal of the stratigraphy of the upper Shoalhaven Group and lower Illawarra Coal Measures, southern Sydney Basin, New South Wales. Proceedings of the Linnean Society of New South Wales, 106: 287-297

Chi G., Giles P.S., Williamson M.A., Lavoie D., Bertrand R. (2003) Diagenetic history and porosity evolution of Upper Carboniferous sandstones from the Spring Valley \#1 well, Maritimes Basin, Canada - implications for reservoir development. Journal of Geochemical Exploration, 80: 171-191.

Cowan E.J. (1993) Longitudinal fluvial drainage patterns within a foreland basin-fill; Permo-Triassic Sydney Basin, Australia. Sedimentary Geology, 85: 557-577.

Dehghani M.H. (1994) Sedimentology, genetic stratigraphy and depositional environment of the Permo-Triassic succession in the southern Sydney Basin, Australia. PhD. thesis, University of Wollongong, Wollongong.

Dehghani M.H., Jones B.G. (1994a) Evolution of the Narrabeen Group Succession in the Southern Sydney Basin. Geological Society of Australia, Abstract No. 37, "12th" Australian Geological Convention, September 1994, Perth.

Dehghani M.H., Jones B.G. (1994b) Sedimentology of Coalcliff Sandstone, Southeastern Sydney Basin: Fluvial Interpretation Based on Bounding Surfaces and Architectural Elements. Proceedings of the Twenty-eighth Symposium on Advances in the Study of the Sydney Basin: 236-243. University of Newcastle, Newcastle.

Dehghani M.H., Jones B.G. (1994c) Scarborough Sandstone in the southeastern Sydney Basin; an Early Triassic sandy to gravelly bed-load fluvial deposit. Proceedings of the Twenty-eighth Symposium on Advances in the Study of the Sydney Basin: 244-251. University of Newcastle, Newcastle.

Dickey P.A. (1981) Petroleum Development Geology. Penn Well Publishing Company, Tulsa, Oklahoma, USA.

Dickinson W.R. (1985) Interpreting provenance relations from detrital modes of sandstones. Nato ASI Series, Reidel, Dordrecht, 148: 333-361.

Dickson T.W. (1967) Stratigraphy of the Narrabeen Group in the southern Coalfield. Geological Survey of N.S.W. Report, GS $1967 / 35$.

Dickson T.W. (1969) Stratigraphy of the Narrabeen Group in the Southern Coalfields, N.S.W. In: Abstracts for the Second Symposium on Advances in the Study of the Sydney Basin, 1967: 23-24. Department of Geology, University of Newcastle, Newcastle.

Dutton S.P., Loucks R.G. (2009) Diagenetic controls on evolution of porosity and permeability in lower Tertiary Wilcox Sandstone from shallow to ultradeep $(200-6700 \mathrm{~m}$ ) burial, Gulf of Mexico Basin, U.S.A. Marine and Petroleum Geology, 27: 69-81.

Ehrenberg S.N., Aagaard P., Wilson M.J., Fraser A.R., Duthie D.M.L. (1993) Depth-dependant transformation of kaolinite to dickite in sandstone of the Norwegian continental shelf. Clay Minerals, 28: 325-352

Ehrenberg S.N., Nadeau P.H., Steen O. (2008) A megascale view of reservoir quality in producing sandstones from the offshore Gulf of Mexico. AAPG Bulletin, 92: 145-164.

EI-Ghali M.A.K., Mansurbeg H., Morad S., Al-Aasm I., Ajdanlisky G. (2006) Distribution of diagenetic alterations in fluvial and paralic deposits within sequence stratigraphic framework: evidence from the Petrohan Terrigenous Group and the Svidol Formation, Lower Triassic, NW Bulgaria. Sedimentary Geology, 190: 299-321

El-Ghali M.A.K., Morad S., Mansurbeg H., Caja M.A., Ajdanlijsky G., Ogle N., Al-Aasm I., Sirat M. (2009) Distribution of diagenetic alterations within depositional facies and sequence stratigraphic framework of fluvial sandstones: evidence from the Petrohan Terrigenous Group, Lower Triassic, NW Bulgaria. Marine and Petroleum Geology, 26: 1212-1227.

Estupinan J., Marfil R., Delgado A., Permanyer A. (2007) The Impact of carbonate cements on the reservoir quality in the Napo Formation sandstones (Cretaceous Oriente Basin, Ecuador). Geologica Acta, 5: 89-107.

Folk R.L. (1968) Petrology of Sedimentary Rocks. University of Texas, Austin, U.S.A.
Gier S., Worden R.H., Johns W.D., Kurzweil H. (2008) Diagenesis and reservoir quality of Miocene sandstones in the Vienna Basin, Austria. Marine and Petroleum Geology, 25: 681-695.

Goldbery R., Holland W.N. (1973) Stratigraphy and sedimentation of redbed facies in Narrabeen Group of Sydney Basin, Australia. AAPG Bulletin, 57: 1314-1334.

Grevenitz P., Carr P., Hutton A. (2003) Origin, alteration and geochemical correlation of Late Permian airfall tuffs in coal measures, Sydney Basin, Australia. International Journal of Coal Geology, 55: 27-46.

Hamilton D.S., Galloway W.E. (1989) New exploration techniques in the analysis of diagenetically complex reservoir sandstones, Sydney Basin, NSW. The APEA Journal, 29: 235-257.

Hammer E., Mork M.B.E., Naess A. (2010) Facies controls on the distribution of diagenesis and compaction in fluvial-deltaic deposits. Marine and Petroleum Geology, 27: 1737-1751.

Hanlon F.N., Osborne G.D., Raggatt H.G. (1953) The Narrabeen Group - its subdivisions and correlation between the south coast and the Narrabeen-Wyong district. Journal and Proceedings of the Royal Society of New South Wales, 87: 106-120.

Heritage Y. (2005) Oil in the Douglas Park Syncline, Southern Coalfield, NSW. B.Sc. thesis, Wollongong University, Wollongong.

Higgs K.E., Zwingmann H., Reyes A.G., Funnell R.H. (2007) Diagenesis, porosity evolution, and petroleum emplacement in tight gas reservoirs, Taranaki Basin, New Zealand. Journal of Sedimentary Research, 77: 1003-1025.

Hlal O.A. (2008) Diagenesis and reservoir-quality evolution of paralic, shallow marine and fluvio-lacustrine deposits. links to depositional facies and sequence stratigraphy. Acta Universitaties Upsaliensis. Digital comprehensive summaries of Uppsala dissertations from the Faculty of Science and Technology, Uppsala.

Islam M.A. (2009) Diagenesis and reservoir quality of Bhuban sandstones (Neogene), Titas Gas Field, Bengal Basin, Bangladesh. Journal of Asian Earth Sciences, 35: 89-100.

Karim A., Pe-Piper G., Piper D.J.W. (2010) Controls on diagenesis of Lower Cretaceous reservoir sandstones in the western Sable Subbasin, offshore Nova Scotia. Sedimentary Geology, 224: 65-83.

Ketzer J.M., Holz M., Morad S., Al-Aasm I.S. (2003) Sequence stratigraphic distribution of diagenetic alterations in coal-bearing, paralic sandstones: evidence from the Rio Bonito Formation (early Permian), southern Brazil. Sedimentology, 50: 855-877.

Kim Y., Lee Y.I. (2004) Diagenesis of shallow marine sandstones, the Lower Ordovician Dongjeom Formation, Korea: response to relative sea-level changes. Journal of Asian Earth Sciences, 23: 235-245.

Lanson B., Beaufort D., Berger G., Bauer A., Cassagnabere A., Meunier A. (2002) Authigenic kaolin and illitic minerals during burial diagenesis of sandstones: a review. Clay Minerals, 37: $1-22$.

Lee Y.I., Lim D.H. (2008) Sandstone diagenesis of the Lower Cretaceous Sindong Group, Gyeongsang Basin, southeastern Korea: implications for compositional and paleoenvironmental controls. Island Arc, 17: 152-171.

Lima R.D., Ros L.F. de (2002) The role of depositional setting and diagenesis on the reservoir quality of Devonian sandstones from the Solimoes Basin, Brazilian Amazonia. Marine and Petroleum Geology, 19: 1047-1071.

Loughnan F.C. (1963) A petrological study of a vertical section of the Narrabeen Group at Helensburgh, N.S.W. Journal of the Geological Society of Australia, 10: 177-192.

Loughnan F.C. (1969) Gosford Formation, red beds in the geology of New South Wales. Journal of the Geological Society of Australia, 16: 403-404.

Loughnan F.C., Goldbery R., Holland W.N. (1974) Kaolinite clayrocks in the Triassic Banks Wall Sandstone of the western Blue Mountain, New South Wales. Journal of the Geological Society of Australia, 21: 393-402.

Loughnan F.C., Ko Ko M., Bayliss P. (1964) The red-beds of the Triassic Narrabeen Group. Journal of the Geological Society of Australia, 11: 65-77.

Luo J.L., Morad S., Salem A., Ketzer J.M., Lei X.L., Guo D.Y., Hlal O. (2009) Impact of diagenesis on reservoir-quality evolution in 
fluvial and lacustrine-deltaic sandstones: evidence from Jurassic and Triassic Sandstones from the Ordos Basin, China. Journal of Petroleum Geology, 32: 79-102.

Mansurbeg H., Morad S., Salem A., Marfil R., El-Ghali M.A.K., Nystuen J.P., Caja M.A., Amorosi A., Garcia D., La Iglesia A. (2008) Diagenesis and reservoir quality evolution of palaeocene deep-water, marine sandstones, the Shetland-Faroes Basin, British continental shelf. Marine and Petroleum Geology, 25: 514-543.

McCaulay G.E., Burley S.D., Fallick A.E., Kusznir N.J. (1994) Palaehydrodynamic fluid flow regimes during diagenesis of the Brent Group in the Hutton reservoir, constraints from oxygen isotope studies of authigenic kaolin and reserves flexural modeling. Clay Minerals, 29: 609-629.

McBride E.F., Abdel-Wahab A., Salem A.M.K. (1996) The influence of diagenesis on the reservoir quality of Cambrian and Carboniferous sandstones, Southwest Sinai, Egypt. Journal of African Earth Sciences, 22: 285-300.

McElroy C.T. (1954) Petrology of sandstones of the southern Coalfield. M.Sc. thesis, University of Sydney.

McKinley J.M., Atkinson P.M., Lloyd C.D., Ruffell A.H., Worden R.H. (2011) How porosity and permeability vary spatially with grain size, sorting, cement volume, and mineral dissolution in fluvial Triassic sandstones: the value of geostatistics and local regression. Journal of Sedimentary Research, 81: 844-858.

Moffitt R.S. (2000) A compilation of the geology of the Southern Coalfield. Notes to accompany the 1:100 000 Southern Coalfield Geology Map. Geological Survey of New South Wales, Sydney, GS1998/277.

Molenaar N., Cyziene J., Sliaupa S. (2007) Quartz cementation mechanisms and porosity variation in Baltic Cambrian sandstones. Sedimentary Geology, 195: 135-159.

Morad S. (1998) Carbonate cementation in sandstone: distribution patterns and geochemical evolution. IAS Special Publication, 26: 1-26.

Morad S., Ben Ismail H.N., Ros L.F. de, Al-Aasm I.S., Serrhini N.E. (1994) Diagenesis and formation water chemistry of Triassic reservoir sandstones from southern Tunisia. Sedimentology, 41: 1253-1272.

Morad S., Ketzer J.M., Ros L.F. de (2000) Spatial and temporal distribution of diagenetic alterations in siliciclastic rocks: implications for mass transfer in sedimentary basins. Sedimentology, 47: $95-120$.

Mozley P.S. (1989) Relation between depositional environment and the elemental composition of early diagenetic siderite. Geology 17: 704-706.

Mullard B. (1995) New South Wales Petroleum Potential. Coal and Petroleum Geology Branch. Geological Survey of New South Wales, Department of Mineral Resources.

Ramm M. (1992) Porosity-depth trends in reservoir sandstones; theoretical models related to Jurassic sandstones offshore Norway. Marine and Petroleum Geology, 9: 553-567.

Retallack G.J. (1977) Triassic Palaeosols in the Upper Narrabeen Group of New South Wales, Part 1 Fractures of the palaeosols. Journal of the Geological Society of Australia, 23: 383-400.

Ryan K.J. (2005) The geological controls of gas in the Narrabeen Group, Southern Coalfield, NSW. B.Sc. (Hons) thesis, University of Wollongong, Wollongong.

Sager M.L. (2007) Petrologic study of the Murrysville Sandstone in southwestern Pennsylvania. M.Sc. thesis, West Virginia University.

Salem A.M., Morad S., Mato L.F., Al-Aasm I.S. (2000) Diagenesis and reservoir-quality evolution of fluvial sandstones during progressive burial and uplift: evidence from the Upper Jurassic Boipeba Member, Reconcavo Basin, northeastern Brazil. AAPG Bulletin, 84: 1015-1040.

Salem A.M., Ketzer J.M., Morad S., Rizk R.R., Al-Aasm I.S. (2005) Diagenesis and reservoir-quality evolution of incised-valley sandstones; evidence from the Abu Madi gas reservoirs (upper Miocene), the Nile Delta basin, Egypt. Journal of Sedimentary Research, 75: 572-584.
Schoen J.H. (1996) Physical properties of rocks: fundamentals and principles of petrophysics. Handbook of Geophysical Exploration Seismic Exploration, 18: Elsevier Science, Oxford, UK.

Smosna R., Sager M.L. (2008) The making of a high-porosity, high-permeability reservoir - the Murrysville Sandstone of Pennsylvania. Northeastern Geology and Environmental Sciences, 30: 87-100.

Storvoll V., Bjorlykke K., Karlsen D., Saigal G. (2002) Porosity preservation in reservoir sandstones due to grain-coating illite: a study of the Jurassic Garn Formation from the Kristin and Lavrans fields, offshore Mid-Norway. Marine and Petroleum Geology, 19: 767-781

Sur K.H., Lee Y.I., Hisada K.-I. (2002) Diagenesis of the Lower Cretaceous Kanmon Group sandstones, SW Japan. Journal of Asian Earth Sciences, 20: 921-935.

Taylor T.R., Giles M.R., Hathon L.A., Diggs T.N., Braunsdorf N.R., Birbiglia G.V., Kittridge M.G., Macaulay C.I., Espejo I.S. (2010) Sandstone diagenesis and reservoir quality prediction: models, myths, and reality. AAPG Bulletin, 94: 1093-1132.

Tobin R.C., Mcclain T., Lieber R.B., Ozkan A., Banfield L.A., Marchand A.M.E., Mcrae L.E. (2010) Reservoir quality modeling of tight-gas sands in Wamsutter field: integration of diagenesis, petroleum systems, and production data. AAPG Bulletin, 94: 1229-1266.

Umar M., Friis H., Khan A.S., Kassi A.M., Kasi A.K. (2011) The effects of diagenesis on the reservoir characters in sandstones of the Late Cretaceous Pab Formation, Kirthar Fold Belt, southern Pakistan. Journal of Asian Earth Sciences, 40: 622-635.

Ward C.R. (1971a) Mineralogical changes as marker horizons for stratigraphic correlation in the Narrabeen Group of the Sydney Basin, N.S.W. Journal and Proceedings of the Royal Society of New South Wales, 104: 77-88.

Ward C.R. (1971b) Mesozoic sedimentation and structure in the southern part of the Sydney basin-the Narrabeen Group. PhD thesis, University of New South Wales, Sydney.

Ward C.R. (1972) Sedimentation in the Narrabeen Group, southern Sydney Basin, New South Wales. Journal of the Geological Society of Australia, 19: 393-409.

Wilkinson M., Milliken K.L., Haszeldine R.S. (2001) Systematic destruction of K-feldspar in deeply buried rift and passive margin sandstones. Journal of Geological Society, 158: 675-683.

Wilkinson M., Haszeldine R.S., Ellam R.M., Fallick A. (2004) Hydrocarbon filling history from diagenetic evidence; Brent Group, UK North Sea. Marine and Petroleum Geology, 21: 443-455.

Wolela A. (2009) Diagenetic evolution of the Ansian-Pliensbachian Adigrat Sandstone, Blue Nile Basin, Ethiopia. Journal of African Earth Sciences, 56: 29-42.

Wolela A.M., Gierlowski-Kordesch E.H. (2007) Diagenetic history of fluvial and lacustrine sandstones of the Hartford Basin (Triassic-Jurassic), Newark Supergroup, USA. Sedimentary Geology, 197: 99-126.

Worden R.H., Burley S. (2003) Sandstone diagenesis: the evolution of sand to stone. IAS Reprint Series, 4: 3-44.

Worden R.H., Morad S. (2003) Clay minerals in sandstones; controls on formation, distribution and evolution. IAS Special Publication, 34: 3-41.

Worden R.H., Mayall M., Evans I.J. (2000) The effect of ductile-lithic sand grains and quartz cement on porosity and permeability in Oligocene and lower Miocene clastics, South China Sea: prediction of reservoir quality. AAPG Bulletin, 84: 345-359.

Zhang J., Qin L., Zhang Z. (2008) Depositional facies, diagenesis and their impact on the reservoir quality of Silurian sandstones from Tazhong area in central Tarim Basin, western China. Journal of Asian Earth Sciences, 33: 42-60

Zhang J.-L., Jia Y., Du G. (2007) Diagenesis and its effect on reservoir quality of Silurian sandstones, Tabei area, Tarim Basin, China. Petroleum Science, 4: 1-13.

Zhang J.-L., Li D-Y., Jiang Z-Q. (2010) Diagenesis and reservoir quality of the fourth member sandstones of Shahejie Formation in Huimin depression, eastern China. Journal of Central South University of Technology, 17: 169-179. 